\title{
Working
}

Paper 
Globalization and Corporate Taxation

Manmohan S. Kumar and Dennis P. Quinn 


\title{
IMF Working Paper
}

Fiscal Affairs and Finance Department

\section{Globalization and Corporate Taxation}

\section{Prepared by Manmohan S. Kumar and Dennis P. Quinn}

\author{
Authorized for distribution by Michael Keen
}

October 2012

\begin{abstract}
This Working Paper should not be reported as representing the views of the IMF, its Executive board, or its management. The views expressed in this Working Paper are those of the author(s) and do not necessarily represent those of the IMF or IMF policy. Working Papers describe research in progress by the author(s) and are published to elicit comments and to further debate.
\end{abstract}

\begin{abstract}
This paper analyzes the extent to which the degree of international economic integration, both financial and trade, affects corporate tax rates. It explores this issue in the context of strategic behavior by countries, taking into account other global and domestic political economy factors. Tax rates are analyzed using a unique tax dataset for advanced and developing economies extending over five decades. We report a number of novel results: there is no general negative relationship between financial globalization and corporate tax rates and revenues - results vary according to country grouping with OECD countries showing a positive relationship; the United States exhibits a "Stackelberg" type of leadership on other countries; trade integration is inversely correlated with tax rates; and public sentiment and ideology affect tax rates. The policy implications of these findings, particularly given budgetary pressures in the aftermath of the global crisis, are noted.
\end{abstract}

\section{JEL Classification Numbers:F2; F41; F59; H25}

Keywords: Corporate tax rates, Tax revenues, Globalization, Strategic behavior

Author's E-mail Address: mkumar@imf.org; quinnd@,georgetown.edu

\footnotetext{
${ }^{1}$ IMF, and Professor, McDonough School of Business Georgetown University, respectively. Quinn acknowledges gratefully support from McDonough School and the IMF. Work on this paper was started when Kumar was a Visiting Professor at the McDonough School of Business, Georgetown University, in 2008. The paper was presented at the 2011 Political Economy of International Finance (PEIF) conference in Berlin, co-sponsored by the Hertie School and the Bundesministerium der Finanzen. The authors thank Stephen Blake, Liz Chalemba, Petra Dacheva, Julia Guerrero, Wilbert Hidalgo, and Xin (Josie) Wang for excellent research assistance, and John Freeman, Michael Keen, Keith Ord, Pietra Rivoli and Steve Weymouth for comments and suggestions. We also thank the participants in the Mortara Center Political Economy Workshop, especially Marc Busch, for their comments, and acknowledge the intellectual contributions of John Freeman and Maria Toyoda to the ideas in this paper.
} 


\section{Contents}

I. Introduction $\underline{3}$

II. Corporate Income Taxes and the Current Macroeconomic Context ................................... $\underline{5}$

III. Financial Globalization, Political Economy Factors, and Corporate Tax Rates................. 1
A. Open Economy Macroeconomics
B. Globalization and Strategic Considerations ....................................................... $\frac{11}{14}$
C. Diffusion of Ideas ....................................................................................

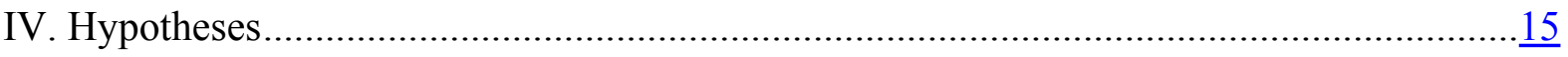

V. Data and Measures, and Methodology.................................................................

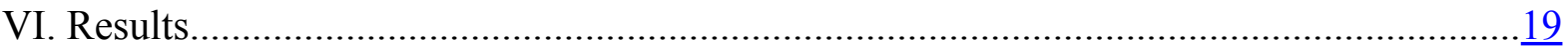

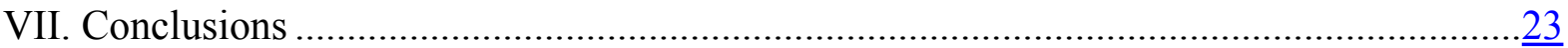

Tables

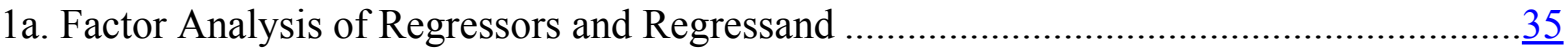

1b. Factor Analysis of Regressors and Regressand ................................................... $\frac{35}{36}$

2. Determinants of Corporate Tax Rates: Full Sample, OECD and non-OECD …................. $\underline{36}$

3. Determinants of Corporate Tax Rates: OECD, Emerging and Developing Economies I ... $\underline{37}$

4. Determinants of Corporate Tax Rates: OECD, Emerging and Developing Economies II..료

5. Corporate Taxation, Capital Share and Countries' Net Asset Position .............................

Figures

1.Central Government Corporate Tax Rates by Region ……........................................ $\frac{25}{26}$

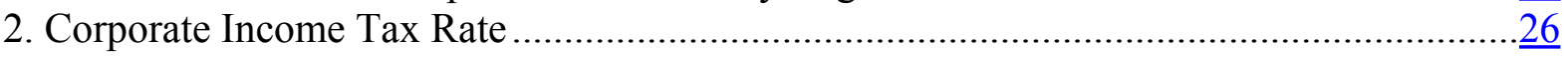

3. Unweighted Average of Central Government Corporate Revenue Central as Percent of GDP.....

4. Home CTR, s vs. Home CTR-U.S. CTR, s-1, Five-year Averages, 1955-2009 ................ $\frac{28}{29}$

5. Home CTR, s vs. Home CTR-U.S. CTR, s-1, Five-year Averages, 1970-79 .....................29

6. Home CTR, s vs. Home CTR-U.S. CTR, s-1, Five-year Averages, 1980-89 ...................... $\underline{30}$

7. Home CTR, s vs. Home CTR-U.S. CTR, s-1, Five-year Averages, 1990-99 .....................31

8. Home CTR, s vs. Home CTR-U.S. CTR, s-1, Five-year Averages, 2000-09......................

9. Home Corporate Tax Rates vs. U.S. Corporate Tax Rates_-Estimates from GMM System

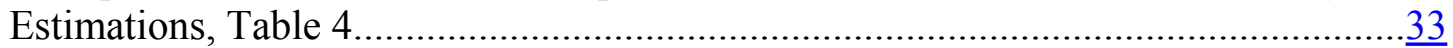

10. Top Personal and Top Corporate Tax Rates Unweighted Global Averages 1981-2005. . $\underline{34}$

Appendix Tables

1. Corporate Tax Revenues as a Percentage of GDP .................................................... $\underline{40}$

2. Country Classification

References 


\section{INTRODUCTION}

A stylized fact about the past three decades is a marked decline in corporate tax rates in many countries. Several studies have explored the role of increasing globalization and international competition for capital in this process of decline (see, for instance, Razin and Sadka 2004, Dreher 2006, Devereux et al 2007, and Devereux 2008; Swank 2006). However, the extent to which the degree of international integration, particularly financial integration, specifically affects corporate tax rates or corporate tax revenues has been much less explored (the main exceptions are Devereux op. cit. and Quinn 1997). Given the sharp increase in globalization (Obstfeld and Taylor 1999), the issue of how and to what extent financial market integration of national economies affects corporate tax policy and tax revenues assumes particular relevance (see Desai and Dharmapala 2010; Zodrow 2010; and the other papers in the December 2010 special issue of the National Tax Journal on capital mobility and taxation).

This paper explores the conditions under which financial globalization $(\mathrm{FG})$ in particular is likely to have a direct effect on corporate tax policy, and when and how that effect is expected to be negative or otherwise. The strategic framework facing governments in which a "Stackelberg" type of leadership by the United States or another major trading partner is also postulated to play a role. The basic notion is that side by side with FG, deviations from U.S. (or other major trading partner) corporate tax rates, up or down, are unlikely to be sustained over the longer term. In this, it provides extensive empirical evidence of the interaction between FG and strategic aspects, which is more general than the strategic behavior modeled by Kempf and Rota-Graziosi (2010). (See also Swank 2006; Swank and Steinmo 2002; Tanzi 1996.) The role of trade integration, as supplementing FG in affecting corporate taxes, is also explicitly analyzed.

The above analysis takes into account a variety of other factors found to be important in determining the statutory corporate tax rates: for instance, there is some evidence that "global sentiment" in the form of attitudes toward the role of markets has changed quite markedly over the past three decades (particularly since the collapse of the Soviet Union), and that has direct implications for the attitudes towards the private corporate sector and its tax treatment (see also Baisinger and Hallerberg, 2004.) Other things equal, this may be expected to exert a downward influence on corporate tax rates. The paper devises a proxy of this change in global "sentiment" and examines the extent to which it has a discernible impact on corporate taxes. (See Quinn and Toyoda 2007 for a more detailed discussion of measuring global sentiment.)

Other domestic political economy factors are also taken into account. For instance, our empirical analysis incorporates the notion that the corporate sector has a strong preference for lower tax rates which suggests that the larger this sector, or the higher its concentration, in a closed economy (in terms of capital share), the lower the rate of taxation. However, with openness, we propose there is diminished concentration and a change in incentives whereby the domestic corporate sector seeks diversified portfolios internationally, reducing its ability and incentive to push for lower rates. We add as conditioning information political economy variables from other studies (see Hines and Summers, 2009; Loretz, 2008; and Plümper et al., 2009). 
The above issues present the picture of a complex interaction between financial and trade integration, strategic factors, global sentiment, and domestic political factors. They are interesting not only in terms of the broader assessment of the determinants of corporate tax rates and benefits and costs of financial globalization, but also specifically in terms of the design of corporate tax policy. They assume particular importance in the aftermath of the global crisis, which has led to a sharp increase in fiscal deficits and public debts, particularly in the advanced economies. The weak, or in some cases, worsening fiscal situation is leading in turn to a reappraisal of tax policies (and fiscal policies generally), with fierce political debates among the political elites of advanced industrial nations on which measures they should adopt to fill the large fiscal gaps.

The paper advances an analytical framework to explore these issues and deduces testable hypotheses for which extensive empirical tests are undertaken. Most of the existing analysis focuses primarily on advanced economies (see, for example, Basinger and Hallerberg, 2004; Plümper, Tröger, and Winner, 2009; Swank, 2006; and Swank and Steinmo, 2002). In contrast, this paper uses panel estimation based on a large number of industrial, emerging market, and developing countries over the past five decades, a range of measures of both FG and tax revenues (to reflect the impact of changes in the tax base, allowances, etc.), as well as tax rate data from the IMF and PriceWaterhouse. The paper examines these issues across large groups of countries over different time periods, taking into account other standard determinants of corporate tax policy, including differential economic growth, investment, country size, and level of financial development. We also allow for parameter heterogeneity across country groupings (e.g., "tax havens" vs. nonbank center OECD nations).

The empirical results are consistent with some of the earlier findings, but also provide a significant number of new and important results:

- $\quad$ Contrary to others, we find in general no negative relationship between the extent of country specific financial integration and corporate tax rates and revenues. Indeed, across some groups of OECD and non-OECD countries, an increase in FG is highly statistically significantly associated with a subsequent upward movement in corporate tax rates and revenues. At the same time, there is little evidence that overall greater global financial market integration leads to downward pressure on corporate tax rates.

- We find evidence of "Stackelberg" type of leadership by the United Statesdeviations above the U.S. corporate tax rates appear not to be sustained over the longer term, but the precise relationship depends on the degree of country specific capital market integration. For the OECD countries, there is a clear indication that cuts in the tax rates by the United States under conditions of financial openness in the home country may increase the probability of home country cuts in the tax rates, whereas increases by the United States ameliorate the pressure for cuts.

- We find that the greater the trade integration of an economy, other things given, the lower its statutory corporate tax rate.

- Global "sentiment" is seen to play a role in putting downward pressure on corporate rates (offsetting the impact of FG). 
- Domestic political economy factors matter. In particular, high share of capital asset concentration in emerging market nations that are relatively closed is negatively and highly statistically significantly associated with lower tax rates.

The paper undertakes extensive analysis to explore the robustness of these findings and, concluding that they are robust, notes a range of channels through which these results might be explained and provides some complementary evidence.

The rest of the paper is organized as follows: Section II discusses policy issues relating to corporate taxation and the broader macroeconomic environment; Sections III and IV discuss the analytical framework and the testable hypotheses, taking into account existing studies. Data and methodology, and results are discussed in Sections V and VI, respectively; the last section concludes. Supplementary results are presented in appendices.

\section{Corporate InCome TAXes AND the CurRent Macroeconomic CONTEXT}

The analysis of the impact of globalization on corporate taxes assumes special importance in the context of the recent sharp deterioration in the fiscal positions of many countries following the global crisis amid continuing competition for mobile capital. At the same time, decisions being taken regarding corporate income tax (CIT) rates in the current highly challenging budgetary environment bring into relief many of the strategic and political economy factors that are seen to impinge on corporate taxation (see discussion below, and studies by Hines and Summers, 2009; Loretz, 2008; and Plümper et al., 2009). In the past, these factors which include fiscal competition under budget rigidities, and equity considerations, have been seen to help explain the absence of a race to the bottom in capital taxation even as globalization proceeded. The conjunctural situation in the aftermath of the crisis presents a more complex dilemma.

The crisis hit particularly hard advanced economies whose gross public debt ratios are projected to average over 110 percent of GDP by end-2012, some 35 percentage points of GDP higher than before the crisis, and the highest since the second World War (IMF, 2010a), and continuing very high fiscal deficits. ${ }^{2}$ Many of these countries face historically high net and gross financing requirements, increasing pressure to find ways to reduce the large deficits and debt ratios. Fiscal policy has already shifted from supporting domestic demand to reducing deficits, with a significant number of advanced economies projected to at least have a declining deficit this year. Most advanced economies, with or without market pressure, are implementing or have announced consolidation plans.

However, it is striking that most of the consolidation plans focus on expenditure cuts, rather than revenue measures, and within the latter, there is no evidence that tax increases are planned to be broad based (IMF, 2010). In particular, while increases in consumption taxes

\footnotetext{
${ }^{2}$ The general government fiscal deficit for the advanced economies is estimated at 6.6 percent of GDP in 2011, following a deficit of 7.8 percent in 2010, and a historical record of 8.9 percent in 2009 (IMF, 2012a). It is projected to remain around 5 percent of GDP for the next two years.
} 
are being contemplated, the impact on direct taxes is much less, and so far there has not been a single case of CIT rates being raised. ${ }^{3}$ This reflects in part the fact that side by side with the increase in deficits and debts is the concern about the weak economic recovery in many economies and the likelihood that potential growth may have declined. In view of that, there is even a consideration being given in several countries to reducing CIT rates to help spur investment activity, including by attracting foreign capital and growth.

In the United States, the "National Commission on Fiscal Responsibility" in its recommendations to cut the U.S. deficit proposed cutting the corporate tax rate (CTR) to 28 percent from the current 35 percent (while eliminating many loopholes, and moving the United States to a territorial system that would not tax profits generated overseas). In Japan and Canada, policy action on this front has already been taken. Japan's Prime Minister Kan proposed a reduction in CIT from 40 to 35 percent; Canada's Prime Minister Harper cut Canada's CTR to 16.5 percent, effective January 1, 2011.

Japan's cut comes despite the fact that it was particularly hard hit by the global crisis, and its already very high public debt ratios exploded further. At end-2010, Japan had a debt ratio exceeding 225 percent of GDP, the highest of any advanced or emerging market economy. At the same time, its general government deficit for 2009-10 averaged 10 percent of GDP. Given its fiscal position, illustrative analysis suggests that it would require an unprecedented adjustment of over 13 percent of GDP to reduce and stabilize the debt ratio at 200 percent of GDP by 2020 . And yet, faced with such fiscal pressure, the government has announced this cut. This action was rationalized on the basis that Japanese companies compete not only with U.S. and European companies, but increasingly equally so with Chinese and Korean companies, which face much lower tax rates. ${ }^{4}$ Thus, despite the fiscal straits, the competition for mobile capital is seen likely to put further pressure on CIT rates.

In addition to the role played by CIT directly, to the extent that emerging markets have been much less adversely affected by the global crisis and their domestic demand growth had been robust, this too is having an impact on discussions regarding CIT. In particular, there has been a sharp increase in the flow of foreign capital, both portfolio and direct investment, to these economies over the last few years, and projections are for these record flows to continue, given the expending domestic markets, high overall growth, and high returns to capital. The impact on FDI flows of these positive developments in emerging markets, which predate the global crisis but have become accentuated since then, is notable. It is estimated that over the next two years, at least a quarter of net profits of U.S. Standard \& Poor's 500 companies will come from emerging market operations (and around half are projected to come from all overseas operations. In terms of the actual FDI flows, the example of India is

\footnotetext{
${ }^{3}$ It is telling that over the two decades prior to the global crisis and during the time that CIT rates were being reduced markedly, the average general government fiscal deficit of the advanced economies declined from around $4 \frac{1}{2}$ percent of GDP at the beginning of the 1990s to around 3 percent of GDP by 2007 (despite a pick up in the U.S. deficit from 2002 onwards), with a corresponding decline in the public debt ratios.

${ }^{4}$ There is also supposed to be some base broadening to accompany the tax cut, which may offset to some extent the adverse effect of the rate cut, but its magnitude is generally considered uncertain.
} 
striking but not unique: total foreign direct investment to India has risen from around $\$ 8$ billion in the two years before the global crisis, to nearly $\$ 37$ billion in 2009-10, and is projected to rise further. In this environment, it is not surprising that there will be an increasing focus on the role that CIT can play in increasing global competitiveness and reducing outflows or stimulating inflows.

Despite these pending cuts, the evidence for the impact of CIT rates on overall GDP growth is mixed, although the corporate tax rate has been seen to be an important determinant of locational decisions (see below). ${ }^{5}$ While results vary across studies (OECD, 2010), some recent analysis by the authors suggests that corporate tax revenues (as percent of GDP) are not significantly related to subsequent growth. For instance, in a fairly general specification that takes into account a variety of robust determinants of growth, the lagged CT variable has a coefficient of -0.31 but a t-statistic of only 0.6 . While this result raises a number of broader issues relating to the role of CIT in influencing aggregate investment and growth, it is also consistent with the role that strategic and political economy factors play in determining the CIT regime in any given country.

\section{Financial Globalization, Political Economy Factors, and Corporate Tax RATES}

We review four strands of literature on the determinants of corporate tax rates drawn from several social science fields. These are open-economy macro-models, empirical studies of tax revenue, models incorporating strategic behavior of governments, and the "diffusion" of regulatory policies literature.

\section{A. "Open Economy Macroeconomics" and the "Race to the Bottom"}

\section{Racing to the bottom?}

Consider first the basic null hypothesis relating to the relationship between financial globalization and CIT rates: that financial globalization and likely globalization in general, leads to lower tax rates on mobile factors of production, reflecting increased competition and the ability of multinational corporations to shift profits through transfer pricing. This hypothesis is derived from one important strand in the existing literature on globalization: that related to multinational activity and corporate taxation (see Tanzi, 1995; Genschel, 2001; Hines, 2005; and Devereux, 2008).

Devereux (2008) puts this competitive argument succinctly when he argues that "the continuing fall in statutory and effective rates of corporation tax in OECD and EU countries is consistent with increasing levels of competition between countries over mobile firms, capital, and profit." He argues that as globalization proceeds further, countries become more open, and transportation and communication costs fall, "it seems likely that rates will also

\footnotetext{
${ }^{5}$ Estimates by de Mooij and Ederveen (2008) suggest that a 1 percentage point cut in the tax rate in a country increases the size of profit reported by a multinational company in that country by 2 percent.
} 
continue to fall."6 The hypothesis is premised on the notion that financial globalization provides increased room for international tax arbitrage. This is particularly so given the evidence of relatively high elasticity of corporate investment decisions to tax rates (Hassett and Hubbard, 2001). It thus suggests that, in the face of increasing global competition in business, with companies moving to countries or jurisdictions with lower taxation on corporate activity, there would be a "race to the bottom" in corporate tax rates. In addition, the growing use of electronic commerce, intra-company trade, and off-shore financial centers is making it difficult to monitor corporate activity and profits, which is likely to tempt governments to lower the statutory rates, and which directly as well as indirectly can have adverse consequences for tax revenues. ${ }^{7}$ The resultant pressures are expected over time to lead to decreased taxation of more mobile factors and, presumably, increased taxation of less mobile factors.

Top corporate tax rates worldwide, indeed, have been declining over the past thirty years. This is illustrated by Figure 1, which charts average CTR by region against the United States (bold black line). The regional averages of the CT have declined from the 35 percent to 55 percent prevailing in 1980 to 25 to 35 percent in 2009. Figure 2 focuses on the averages in the OECD. The drop in the CTR in the United Kingdom from 52 percent to 35 percent between 1982 and 1986, and more importantly, in the United States by the Tax Reform Act of 1986 was quickly mirrored among many OECD nations. It is quite striking that the median CT in the largest 19 OECD countries fell from 50 percent in 1982 to 34 percent by 2003. At the same time, the cross-country variation in CT rates declined markedly: in 1982, half of the countries had statutory tax rates between 43.8 and 55 percent, a range of 11.2 percentage points. Already by 2003 , that range had declined by more than half, to 5.3 percentage points (CBO, 2005), and fallen further still since then. The decreasing rates among OECD nations have left the United States at the top of the CTR table. Special note should be taken of Ireland and Iceland, both of which dramatically cut their CTRs prior to their financial crises. The evidence for emerging markets and developing countries has been much less comprehensive, but it is evident in Figure 1 that many of these countries in Asia and Latin America have also seen a lowering of corporate tax rates.

Hines (2005) argues that the decline in statutory CIT rates during the 1980s and 1990s supports the premise that mobile capital received favorable tax treatment as a result of tax competition. In support, he highlights two facts: (1) the average effective foreign tax rates of U.S. multinationals firms fell by almost half over this period (from 43 percent in 1982 to 26 percent in 1999); and (2) while small countries taxed corporate income at significantly lower rates than larger ones in the early 1980s, there was no substantial difference between small and large countries "implying that large countries set their tax rates in response to the same competitive pressures that small countries have always faced.” Hines (op. cit.)

Devereux et al. (2007) investigate whether the OECD countries compete with each other over corporation taxes, and whether such competition can explain the fall in statutory tax rates

\footnotetext{
${ }^{6}$ See also Devereux and Klemm (2002) and CBO (2005).

${ }^{7}$ Tanzi (op. cit.) refers to these as "fiscal termites."
} 
during 1980s and 1990s. They find, however, the decline in the statutory rates is consistent with their theoretical model's prediction of a decline in the equilibrium rates, and is almost entirely explained by the more intense competition following the relaxation of capital controls.

Hines and Summers (2009) argue that globalization increases financial pressures on governments by increasing the demand for government spending while making it more costly to raise tax revenue. In particular, countries with small open economies have relatively mobile tax bases, and rely less on corporate and personal taxes than do other countries. Intriguingly, they show that other things given the smaller the population, the smaller the ratio of personal and corporate income tax collections to total tax revenues. They conclude that "since the rapid pace of globalization implies that all countries are becoming small open economies, the use of expenditure taxes is likely to increase, posing challenges to governments concerned about recent changes in income distribution."

\section{Racing to raise revenues?}

Open economy macro theory and falling rates notwithstanding, revenues from corporate taxation have risen steadily over 30 years. Figure 3 plots regional averages of corporate tax revenue as a percentage of GDP against U.S. tax collections. For the United States and all regions save for Sub-Saharan Africa (SSA), revenues have risen over time. The trend lines derived from the data for all regions except SSA are upward sloping. For the average member country of the European Union (EU), for example, corporate tax revenues as a percentage of GDP have risen in the past 35 years from 1.6 percent of GDP in 1980 to 3.4 percent in 2009, a year of financial crisis. The 30 years between 1980 and 2009 are a period of rapid financial globalization among EU member countries with no significant capital controls remaining within the EU. Top corporate tax rates have fallen on average during the same period, but the tax base has been broadened through reductions in incentives and other deductions, and base-broadening has contributed to the steep rise in corporate tax collections. ${ }^{8}$ The trend in corporate tax revenues is also observed in emerging market economies, where relative to the total, corporate taxes account for almost 20 percent of total tax revenue, the highest ever recorded.

Here it is worth noting that a key study by Quinn (1997) had found that capital account liberalization was associated with increasing corporate tax revenues, and not with the erosion of the tax base. He also did not find that corporate tax arbitrage particularly affects governments in emerging markets. Krogstrup (2008), using Quinn's capital account liberalization index, also finds that capital taxes are positively correlated with capital account liberalization. In another recent study, Dreher (2006), utilizing a wide range of indicators of globalization which are generally substantially correlated, found that over the period 1970 to 2000 in the OECD countries, taxes on capital are seen to significantly increase with globalization. This result is shown to be robust across a range of dynamic specifications.

\footnotetext{
${ }^{8}$ See Devereux, Griffith, and Klemm (2002) for a review of the policy debate around cutting top tax rates while "tax-base broadening." See also Swank and Steinmo (2002).
} 
The combination of declining statutory and effective corporate tax rates, particularly in the industrial countries, and high corporate tax revenues can be explained in a number of different ways (see Kumar et al., 2007). First, the corporate tax base has been broadened as a result of reduction of exemptions. ${ }^{9}$ Second, corporate tax revenues are highly cyclical and had been boosted by the strong global growth and record-high profits prior to the global crisis. Third, the apparent increased volatility of profits coupled with imperfect loss offset provisions, could also boost corporate tax collection. Fourth, the shift from personal income to corporate taxes may also have boosted corporate tax revenue. In the EU countries, lower corporate taxes are reckoned to increase the corporate tax base by encouraging small businesses to incorporate, which shifts tax revenues from personal to corporate income tax. A similar impact would be observed as a result of shift from debt to equity financing.

Moreover, given the predictions from the early open economy macromodels, a pressing question has been why rates haven't moved even lower, perhaps even to zero. Addressing the discrepancy between theory and evidence in a paper entitled "Why is there No Race to the Bottom in Capital Taxation?" Plümper, Troeger, and Winner (2009) argue that fiscal rules and equity norms (measured by Gini coefficients) put upward pressure on effective capital taxation, in terms of both rates and revenue. While "tax competition" does cause some shifting of tax burdens to less mobile factors, fiscal rules and social fairness norms can be important determining factors. Their model treats the outcome of tax competition as one argument in the government's utility function, the others being public expenditure and tax equity. While tax competition causes a reduction in taxes on mobile capital and an increase in the tax rates on relatively immobile labor, taxes are affected by budget constraints.

Governments that are least restricted by such constraints and equity norms cut tax rates to levels slightly below the lowest tax rates of those countries, in which governments are more constrained.

Other studies offer related findings. Cao (2010) emphasizes the role of constraints that prevent policymakers from adopting optimal capital tax rates and notes the importance of domestic political institutions, such as the number of veto players, the nature of partisan politics, the strength of the labor union and corporatist decision making, and characteristics of the electoral system in influencing capital taxation. He concludes that there is sufficient evidence to suggest that CIT rates reflect both conditions at the domestic level and strategic interactions at the international level. Hays (2003) finds that majoritarian versus consensual political institutions influence tax rate policies. These studies are consistent with the "system of constraints" results in Swank and Steinmo (2002) as well as with the "tournament" model in Basinger and Hallerberg (2004).

Hence, an alternative approach can be mapped from several separate strands of literature and a number of empirical studies (see Garrett, 1995; Quinn op.cit.; Swank, 2001; and Dreher, 2006). These suggest that the relationship between the change in the degree of FG and

\footnotetext{
${ }^{9}$ For illustration, consider the case of India: increasing financial globalization led to pressures to reduce CIT rates and for major improvements in tax administration. While the former did not materialize due to a variety of political economy factors, there were large gains in revenues.
} 
corporate tax rates need not be negative, and certainly not monotonic. Thus, while as shown above, the trend toward a decline in capital tax rates globally is unmistakable, there is a broad range of other factors that have a bearing on the corporate tax rates, which after all primarily affect economic behavior of domestic agents as they respond to the incentives that tax creates. In addition, provision of services financed by taxation, including public investment and a number of aspects related to policy credibility and signaling can also be important. Once these aspects are taken into consideration, it is not evident that the alternate support would be rejected.

\section{Rates and revenues: No race?}

There are a number of specific elements that lead to an expectation of support for the alternate approach that increased financial integration is not necessarily associated with either declining rates or revenues. First, there is abundant evidence that despite the increasing flexibility of production, it is often quite costly to move physical assets across countries. Hence, higher corporate tax rates in one jurisdiction does not automatically mean that location of production will be shifted or that there will be a tendency to lower tax rates to attract activity. Second, capital flows to places where it makes profits, not where its costs or any particular element of costs such as taxes are lowest. Companies take into account the services provided by the host country's public sector (such as infrastructure, public administration, and law enforcement) and financed by tax revenues, as well as the macroeconomic and political stability (Steward and Webb, 2006). What is more important than the tax burden alone is the balance of these costs and benefits. Third, and relatedly, corporate employees also tend to give importance to the cost and quality of publicly provided services, including education and health care. If higher tax costs are associated with improved services, this may not necessarily lead to a pressure to reallocate to other tax jurisdiction, with lower quality of publicly provided services.

The notion of a rather simple relationship between financial globalization and CIT rates is particularly open to question in light of some evidence relating to strategic considerations in setting CIT rates. Assuming an oligopolistic type of environment, the role of a "Stackelberg" leader, possibly a major trading partner or the United States as the largest economy, is potentially important. The idea is that the CIT rate in the "leader" country is a key element in the rate determination by the "follower" country a la Stackelberg (Swank, 2006; Swank and Steinmo, 2002; Tanzi, 1996.). The issue then becomes the extent to which, other things given, deviations above U.S. corporate tax rates can be sustained over any appreciable period of time and whether governments will chose to maintain rates below the United States. We explore this in the next section.

\section{B. Globalization and Strategic Considerations}

Regarding strategic decision making, Kempf and Rota-Graziosi (2010) develop a model where tax-setting is endogenous, and show that tax rates are higher when countries move sequentially than when they move simultaneously. They generalize the assumption made by Baldwin and Krugman (2004) regarding Stackelberg leadership - that the larger country or the core country behaves as a leader. The latter finds support in studies by Altshuler and Goodspeed (2002) that showed that European countries follow the United States when they 
set their tax rate. In the case of European countries, specifically Devereux et al., (2007) shows that large countries behave as the leaders.

Loretz (2008) also emphasizes the role of increasing tax competition in an environment of increased globalization affecting the whole structure of taxation. He argues that the decline in corporate tax rates over the past two decades was accompanied by tax base broadening and a comparable reduction in personal income tax (PIT) rates early on in the period. He shows that increasing tax competition has induced a shift towards consumption taxes even while taxes on mobile factors are reduced.

A key assumption of most of this literature is one of U.S. leadership. A second assumption is that the leader's tax policies are set exogenously (Kempf and Rota-Graziosi, 2010, is an exception.)

The first assumption-U.S. leadership — will be explored explicitly below. The second assumption can be considered sound, given the legislative history of the two major revisions of capital and corporate taxation, the 1981 Economic Recovery Act, and Tax Reform Act of 1986 (the latter reduced the U.S. top corporate statutory rate from 50 percent to 35 percent). Both of these acts came under the Reagan administration, and were rooted in shifting beliefs about the efficacy of high levels of corporate and capital taxation, and not in pressures from outside the United States (Berman and Pagnucco, 2010; Boskin, 1996; Davies, 1986). A further contributor to changes in U.S. tax policy has been the lobbying and campaign contribution activities of U.S. domestic firms (Quinn and Shapiro, 1991; Richter, Samphantharak, and Timmons, 2009). Desai and Dharmapla (2010) note that "strong fence" corporate tax policy in the United States has been largely impervious to international trends in the corporate tax policies in other countries.

U.S. tax policy also provides incentives for larger countries at least to maintain some taxation of corporate income. The United States taxes its firms on a "worldwide" basis in which residents (firms and individuals) are taxed on all income, whether derived abroad or at home. (see Joint Committee on Taxation, 2008, pp. 3-5, for a discussion of the features of U.S. corporate tax law.) Income earned abroad is not taxed until the income is repatriated home. When repatriated, this income is not double-taxed in that U.S. firms are able to claim credit for income taxes paid to other countries. This has provided an incentive for important economic partners to maintain some taxation of corporate income: e.g., income earned by U.S. firms in Germany is taxed at 35 percent by the United States, less the taxes paid to Germany. Germany, by cutting its tax rates to below those of the United States, simply provides increased revenues to the U.S. Treasury.

Given the strategic aspects of global tax policies, tax policies will likely vary systematically by type of economy. Of particular note regarding corporate tax policies are countries widely referred to as "tax havens" (see Gravelle 2010 for an extensive review and discussion of the policies of tax havens and their consequences for other countries). U.S. firms have "parked" roughly \$1 trillion in "stranded profits" in tax havens (Drucker, 2011). Gravelle (2010, p. 3) provides a list of countries widely considered to be tax havens, and we use the list to define 
"banking centers." ${ }^{10}$ Corporate taxation in economies based on oil exports is likely to show a different evolution from OECD economies, given the strategic incentives facing those governments. Aizenman and Jinarak (2009) demonstrate that lower income countries with weaker government capabilities have incentives to tap different revenue streams from wealthier emerging market countries with stronger fiscal capabilities. We explore below whether lower income and higher income emerging market economies demonstrate differing determinants of corporate tax policies.

\section{Globalization and Elite Incentives}

The role of domestic political economy factors needs to be taken into account in our exploration. Since we are examining the average (statutory) corporate tax rate, and not the effective rate faced by foreign multinationals, the bulk of the impact of any given CIT burden is felt by the domestic corporate sector (although of course at the margin it would affect the competitive challenge from external capital inflows). The size of the domestic corporate base (relative to labor) and the extent to which the domestic corporate structure is concentrated and hence facilitates organizing for lower rates, would likely be important.

This is in contrast to an assumption in the open economy macromodels of corporate taxation, which is that, in a closed economy, governments are able to tax capital and corporate income at very high rates precisely because of domestic political economy arrangements. Holders of capital are generally assumed to be less numerous than holders of labor, and to be outvoted in the closed economy case. Democracies will generally tax capital income at high rates under conditions of financial and economic closure (see, fore xample the models in Boix, 2003, Chapter 2).

Elites who own and manage corporations, however, have a strong incentive to resist high rates of capital and corporate taxation. Insofar as tax policy can be considered to have "public goods" properties, the logic of collective action will apply. In this closed economy context, when capital asset ownership is concentrated, elites are likely to be more successful in organizing to resist higher rates of capital taxation. In the context of diffuse asset ownership in a closed economy, in contrast, the elites are less likely to be able to organize, and tax rates are likely to be higher.

With economic openness, especially financial openness, elite incentives regarding tax policy change. Modern portfolio theory proposes that an internationally diversified portfolio with asset holders holding small stakes in many types of assets produces long-run economic gain. Liberalizing capital account flows helps these domestic capital owners create internationally diversified portfolios, but it also lessens their ability (or perhaps even their willingness) to organize to influence domestic tax policy. These capital owners then also confront global tax rates on their new portfolios that they cannot begin to organize to influence.

Elites in a closed economy case are therefore holders of an undiversified investment

\footnotetext{
${ }^{10}$ For our purposes, the relevant countries are the Bahamas, Bahrain, Barbados, Hong Kong, Ireland, Mauritius, Panama, Singapore, and Switzerland. See Gravelle 2010.
} 
portfolio, with undiversified political risk. The greater the concentration of capital asset ownership, therefore, the more likely it is that the holders of this undiversified economic and political portfolio are able to organize successfully to influence the terms of taxation. Concentrated elites are better able to organize to use "voice" to reduce tax rates. However, post-liberalization elites are able to form international diversified portfolios, and have the ability to diversify their domestic political risk. In this context, "exit" becomes the main vehicle for influencing tax policy. (See Freeman and Quinn 2012 for an extended discussion of elite incentives in open and closed economies.)

In these ways, financial globalization potentially has much more complex effects on corporate taxation. For one, the "identity" of holders of domestic assets changes; both international and native elites hold assets. And international investors holding diversified portfolios are likely to be less responsive to domestic tax policies than the undiversified domestic holders of specific assets in closed economies. Asset concentration, therefore, will have an effect on the corporate tax rate conditioned on financial globalization. ${ }^{11}$ A related issue is the extent to which rising firm profitability from financial globalization could allow governments to actually raise tax rates without any pronounced deleterious effects on competitiveness. Numerous studies have documented that economic integration is associated with increasing firm profitability (see Lorentz, 2008, for a review).

\section{Diffusion of Ideas}

A plethora of recent papers show international economic reforms spread among countries. Among recent works on the diffusion of ideas and international economic reforms are Cao, 2010; Chwieroth, 2007 and 2010; Henisz, Zelner, and Guillen, 2005; Quinn and Toyoda, 2007; and Swank, 2006 (see Dobbin, Garrett, and Simmons 2006 for a review).

There is an important dimension related to diffusion of global "sentiment" with regard to the role of markets versus governments that is likely to influence tax policy. Loretz (2008) notes that, until the late $2000 \mathrm{~s}$, trends in tax rates of personal income tracked closely trends in tax rate of corporate income. Peter, Buttrick, and Ducan (2010), in a panel of 189 countries, demonstrated steady declines between 1981 and 2005 in top personal income tax rates.

The core underpinning of the open economy macro models of capital and corporate taxation has been that the mobility of factors influences the tax rates. If tax rates on relatively immobile factors (i.e., people) track similarly to tax rates on mobile factors (i.e., capital), forces beyond factor mobility are likely at work. Ideas about the relative merits of markets and governments in allocating resources are such a force. See Loretz (2008), Quinn and Toyoda (2007), and Swank (2006) for related arguments.

To the extent that the collapse of the Soviet Union led to a rejection of the extreme form of socialism and recognition of the importance of markets, there would be an expectation that

\footnotetext{
${ }^{11}$ A different set of considerations suggest that even where a reduction in corporate tax rates might be warranted, the issue of distributional implications might preclude this (the argument is similar to that relating to tax reform more generally; see Auerbach and Hassett, 2005).
} 
the very high CIT regime associated with that socialist political economy framework would also be discredited. To take this factor into account, it is particularly important to have as broad a sample of advanced, emerging market and developing countries as possible, and to have indicators of public sentiment in the analyses.

\section{HYPOTHESES}

Based on the above analytical considerations and existing evidence, we empirically investigate the following:

Our main hypothesis is that strategic considerations plays a key role, and the degree of FG interacts with this strategic aspect: for a given FG, governments with rates above the U.S. rate tend to cut rates, and governments with rates below the U.S. rate tend to raise rates.

H1 Home countries tax rates are set conditionally on the US corporate tax rate, with governments with rates above the US rate tending to cut rates, and governments with rates below the US rate tending to raise rates

Our main null hypothesis (H1) is that home country tax rates are influenced by financial globalization at home and abroad. But contrary to some existing studies, we postulate that with global financial integration comes higher corporate profits and increased incentives for governments to maintain or (depending on US rates) raise corporate tax rates.

H2 Global financial openness will be associated with increasing corporate profitability and increased rates of profit taxation.

The overall relationship between domestic CTI, and globalization thus depends on a complex of factors including the degree of a country specific financial integration, overall financial globalization, U.S. (or dominant partner country) tax rates, and a variety of other global and political economy factors. With regard to trade openness, we postulate an inverse relationship with the degree of openness and CT rates.

H3 Increasing trade integration is associated with subsequently decreasing Corporate tax rates.

In terms of the conditioning variables, it is expected that the larger the share of the corporate sector (and the higher the asset concentration in the economy) in closed economies, the lower the rates. And public sentiment and public opinion also influences corporate tax rates: as preferences for increased equity and increased support for left-ideology increase, corporate tax rates increase. 


\section{Data And Measures, and Methodology}

\section{A. Data and Measures}

Corporate tax rates and corporate tax revenues. We construct a panel with central government and general government tax rates. For central government tax rates, we have 4,337 observations for 141 countries in a strongly unbalanced panel. Matching these data to other data, we have useable data for 94 countries starting as early as 1953 and ending in 2009. The corporate tax revenue as percent of GDP has 2,048 observations, with no useable observations prior to 1980 and ending in 2009. Both series are affected by frequent gaps from year to year in the data.

The sources for the data are internal IMF sources from the Fiscal Affairs Department, the OECD Corporate Tax Database (II.1), annual corporate tax surveys from PriceWaterhouseCooper, Ernst and Young, and the University of Michigan Tax Center. The data for government revenues as a percentage of GDP comes in part from the IMF's Government Finance Statistics (GFS) Database. An important gap in the data is occasioned by the divergence in accounting methods used in the 1986 and 2001 GFS revisions.

To offset data limitation and data error, we use 5-year annual panels. The panels are strongly unbalanced. We have 573 5-year averaged panels for up to 94 countries. Appendix Table 3 lists the countries in the investigation and the categorizations we use.

Asset Concentration and Inequality. Rodriguez and Ortega (2006) create a variable they term "capital share" from United Nations Industrial Organization (UNIDO) survey data of manufacturing firms worldwide. Capital share is computed as 1 minus the ratio of wages paid to employees by the firm value added. This indicator is used in Houle (2009) as a measure of income inequality, but we use it here as an indicator of capital asset concentration in an economy. We use Version 2 of the UNIDO data. The capital share data do have some important limitations. ${ }^{12}$ Of particular note is that the sample size of the firms responding to the survey varies markedly within country from year to year in some countries. We also use Gini coefficients with "Dollar Kraay" adjustments (Dollar and Kraay, 2002) to explore the role of inequality in taxation. Plömper et al. (2009) use a pre-tax indicator of inequality, which is unavailable for most countries in the sample, so the results between their study and this will not be strictly comparable.

Economic Data. We use Penn World Tables for domestic economic variables, including

\footnotetext{
${ }^{12}$ Some methodological issues discussed in Rodriguez and Ortega (2006) include measurement error and national differences in reporting. Since capital share (CS) is taken as CS $=[1-($ Wages and Salaries/Value Added)], and since it is computed from surveys of larger incorporated firms, countries with large informal sectors or many smaller business will, through data omission on wage data, have larger capital shares (since the wages paid in the informal sector and in small businesses will be credited to the capital share). Many advanced economies also report fringe benefits and other forms of compensation as wages, which further decrease their capital share. A second issue that Rodriguez and Ortega consider is that developing countries have stronger agrarian sectors, which are not considered in the industrial surveys. A third issue is that emerging market countries, while having fewer incorporated firms and larger agrarian sectors, also have firms that exhibit lower labor productivity, which translates into lower wages (and higher capital shares).
} 
growth, income per capita (ppp adjusted), population growth, trade openness, investment share, and government share of economy. We use, as a measure of financial development, a nation's liquidity (M3) as a percentage of GDP from IMF sources, using updates of Beck, Demirguc-Kunt, and Levine (2000).

Financial Globalization. We use de facto and de jure measures of international financial integrations. For the de facto indicators, we use the data on international financial assets (LogAssets-outward FDI and portfolio flows as percent of GDP) and international financial liabilities (LogLiabilities-inward FDI and portfolio flows as percent of GDP) from Lane and Milesi-Ferretti (2007). These indicators, when summed, produce TOTAL. We operationalize de facto international financial regulation (CAPITAL) as an indicator in change in international financial openness or closure, which is described in Quinn (1997), and Quinn and Toyoda (2007). CAPITAL is the main element of capital account openness created from the text published in the annual $A R E A E R$ volume that reports laws used to govern international financial transactions. These indicators take a different approach in creating an index for a government's policy stance toward capital account liberalization and financial current account liberalization by offering a measure not only for the existence (absence) of restrictions but also for the severity or magnitude of those restrictions. Data for up to 122 countries through 2007 are available. GlobalCAPITAL is the world average of capital account openness net of the home country's contribution to the indicator.

Ideology and Voter Sentiment. We operationalize global anti-capitalist ideology by using the percentage of votes across countries garnered by Communist Parties (hereafter "CP votes"). This indicator is used in Quinn and Toyoda (2007) to measure global policy sentiment. We include data only from countries where all parties, including the CP (or a renamed subsidiary) have been free to compete in secret balloting from 1949-52 through 2006 . $^{13}$ There are 23 such countries in the data set. ${ }^{14}$ The indicator captures the extent to which voters worldwide have ideological preferences for higher taxes on corporate and capital income (see also Baisinger and Hallerberg, 2004, on the role of ideology).

\footnotetext{
${ }^{13}$ The data are provided in an appendix available from Quinn, but have some limitations: (1) The German CP was banned for 10 years in the late 1950s and early 1960s. Germany's data are therefore excluded. (2) CPs frequently joined in alliance with other parties. Where, as in the case of Finland in 1991 and 1995, the CP is the dominant partner (of the Left-Wing Alliance), the Left-Wing Alliance's total votes are entered as CP votes. Italy in 1948 and Denmark (Unity List) are treated that way. In other cases, such as Sri Lanka where the CP is a junior partner in the People's Alliance, the CP vote total is entered as zero. The CP of the Netherlands (Green Left) is treated this way. (3) CPs frequently fissure. Where the resulting parties describe themselves as loyal to Marxist-Leninist theory, the vote totals are summed. This is the case for India, where the CP of India (proSoviet) and the CP-Marxist (pro-Chinese) split in 1964. In Israel, Maki and Rakah are summed. Hadash is treated as the successor party. (4) A few CPs, notably the Vansterpartiet in Sweden and Italy's CP, which was the largest and most successful one in Western Europe, have gradually broken with Leninism (see their history at http://www.vansterpartiet.se/ and http://www.fact-index.com/i/it/italian_communist party.html.). For the purposes of this paper, they are treated as being a CP.

${ }^{14}$ These are Australia, Austria, Belgium, Canada, Denmark, Finland, France, Iceland, India, Ireland, Israel, Italy, Japan, Luxembourg, Malta, the Netherlands, New Zealand, Norway, Sri Lanka, Sweden, Switzerland, the United Kingdom, and the United States.
} 


\section{B. Models and Methods}

Since we are interested in exploring the separate and joint effects of financial globalization and tax competition on corporate tax rates, pooled, cross-section, and time-series (PCSTS) models are useful in evaluating the question of why, over time, some countries changed tax policies and had changing receipts. That is, the variation in the dependent variables comes from both the dynamic and cross-sectional factors.

By including lagged levels of the dependent variable, we no longer include country fixed effects in the model (as the inclusion of fixed effects induces serial correlation in these models, presumably because of the correlation between the fixed effects and the lagged dependent variables). These specifications are 5-year non-overlapping models, with the units denoted by $\mathrm{i}=1,2, \ldots, \mathrm{x}$ and the index $s$ representing 5-year intervals, starting at 1955-59 and continuing onward. This means, for instance, that Corporate Tax Rates ${ }_{i, s}$ for the $\mathrm{s}=1985-$ 1989 period is analyzed using data from $\mathrm{s}-1=1980-84$ period.

OLS estimations, while useful in exploring the structure of the relationships, are potentially plagued by several methodological problems including (1) unknown forms of heteroskedastic errors; and (2) hard-to-observe persistence in explanatory variables that is correlated with the error term. Furthermore, the relationships between corporate tax rates and other variables are potentially endogenous. Five-year lagged averages in variables attenuate, but do not eliminate, the possible bias.

To address both the persistence problem-possible correlation between the endogenous variables and the error term - we use GMM-system estimation, which is a form of IV regression. This method is due to Arellano and Bover (1995) and Blundell and Bond (1998). An advantage of the use the GMM system estimation in a setting with extensive measurement error is that valid instruments (assessed through the Sargan test) reduce measurement error.

Our GMM system design includes an additional transformation of the right-hand side variables. The tax rates and tax revenues variables, and right-hand side variables as well, exhibit persistence over time, a persistence that is exaggerated by 5 -year averaging. The same is true of the lags of the endogenous variables. The persistence in these variables could make them correlated with the error term. This would produce biased estimates. We therefore difference these variables. Finally, note that in GMM estimation, the absence of serial correlation in the main model is indicated by negative, statistically significant first order AB $\mathrm{m} 1$ test, combined with no statistical significance on the AB m2 test (Doornik and Hendry, 2001, p. 69).

With the differencing transformation, additional conditioning information (controls) and allowance for persistence, the GMM-system model for corporate taxation (1) is 


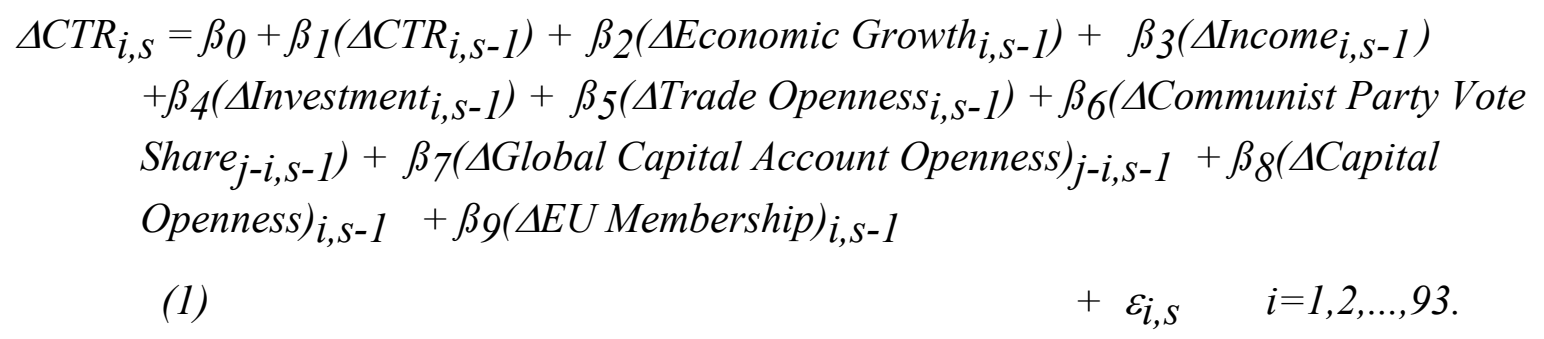

To the model, we add indicators of a country's tax rate compared to the U.S. tax rate, or $\beta 10\left(\Delta\right.$ homeCTR-USCTR $\left._{i, s-1}\right)+\beta_{11}(\Delta$ homeCTR-USCTR $i, s-1)$. The specification allows for the relationship between the home country tax rate and the U.S. rate to be quadratic. ${ }^{15}$ To achieve serially uncorrelated residuals, a second lag of the dependent variable is included where necessary $\left[\beta_{2},\left(\Delta C T R_{i, s-2}\right)\right]$.

The (internal) instruments for the lagged endogenous variables in (1) are the third lags of the levels of the lagged endogenous variables, and the second lag of the differences of the lagged endogenous variables. ${ }^{16}$ The global variables are treated as being exogenous.

We explicitly allow for parameter heterogeneity in the models. Countries with different "strategic" incentives are likely to behave accordingly. Countries that are "tax havens" and countries with oil as the main commodity are likely to have tax policies strikingly different from other countries. We also allow for OECD and non-OECD countries to have different parameter estimates. A further refinement is to divide the non-OECD, non-oil, nonbanking countries into lower income and higher income countries (for this draft). A natural breakpoint in the data is the gap between Haiti and Thailand in 1970. Countries with incomes of $\$ 1750$ (2006 U.S. dollars chain-indexed) per capita and below are grouped with Haiti as lowincome countries.

\section{RESULTS}

Scatterplots begin our empirics (see Figures 4 to 8). For these scatterplots, the y-axis is a country's change in its corporate tax rate in period s (e.g., 2005-09); the X-axis is the home country's tax rate in the prior s-1 period (2000-04, e.g.) minus the U.S. CTR in the same prior period, $\mathrm{s}-1$. Figure 4 plots the data for all countries for all years; the remaining figures show the decade by decade evolution of the plots: Figure 5, 1970-79; Figure 6, 1980-89; Figure 7, 1990-99; and Figure 8, 2000-09.

Our core expectation is that, for any given degree of FG, countries over time will respond to the U.S. tax rate in a revenue maximizing manner. An implication is that most countries will

\footnotetext{
${ }^{15}$ An additional specification, where the U.S. tax rate is interacted with various independent variables will also be estimated.

${ }^{16}$ All GMM estimations are done in PCGive 12. The model settings in PCGive 12 for the GMM system estimation include 1-step estimates with robust standard errors, the transformation set to "differences," and specification tests for two lags of serial correlation.
} 
be clustered in either the northwest or the southeast quadrants: countries with rates below the U.S. that are subsequently raising rates $(\mathrm{NW})$ and countries with rates above the U.S. rate that are subsequently cutting rates (SE). Figure 4 shows that a moderately strong unconditional correlation over time with the core hypothesis, with most countries aligned NW to SE.

In the early periods of the sample, substantial numbers of countries that were below the U.S. rates subsequently raised them. By the end period, 2000-09, no country occupied the northeast quadrant - taxes higher than the United States' subsequently raising them. A significant number of countries occupied the southwest quadrant in 2000-09-rates below the United States' and decreasing subsequently. The dominant trends are countries to clustered around the U.S. rates in something of a quadratic relationship (-X + -X-squared). Over time, the dominant pattern in the data is the move from the northwest (below the U.S. rate and subsequently raising) to southeast (above the U.S. rates and dropping).

To better understand the panel structure of the data, we use factor analysis to identify underlying components or factors that explain the pattern of correlations in a data set. Once the number of components or factors is established, factor analysis allows us to identify which variables in a data set are correlated with which factors, and how strongly.

Tables $1 \mathrm{a}$ and $1 \mathrm{~b}$ report the results of our factor analyses of the corporate tax rate regressors and regressands. Table 1a uses the basic regressors from Model 1; Table 1b includes additional regressors representing international financial integration and financial development, though the inclusion of the additional variables leads to a 45-percent reduction in the numbers of observations and an omission of the period before 1975. Four wellidentified underlying variables or factors account for roughly 70 percent the variance in the data in both Tables $1 \mathrm{a}$ and $1 \mathrm{~b}$.

In Table 1a, Corporate Tax Rates load negatively on the first and third factors, which account for 28 percent and 10.8 percent of the variance in the data, respectively. Corporate tax rates load positively, along with Communist Party Vote shares and in opposition to Global Capital Openness on the first factor, and load negatively, in contrast to trade openness, in the third. In Table $1 \mathrm{~b}$, which contains a broad range of data, Corporate Tax Rates load negatively on the second factor, which accounts for 19 percent of the panel variance, and does so against Trade Openness, Inward Investment (Liabilities), and Outward Investment (Assets). Communist Party Vote Shares and Global Capital Openness load positively and negatively on a single factor as a high level (>.9).

The results of the factor analyses are that corporate tax rates are part of an underlying variable representing facets of international integration, and that the relationship of higher taxes in this underlying variable with other processes of international integration is negative. Further, corporate tax rates are linked, in Table 1, both to global financial openness (negatively) and to public sentiment about those flows.

An implication of the factor analyses is that causal relationships between variables representing forces of international integration and corporate tax rates cannot easily be 
assessed. The variables representing economic integration and corporate tax rates are, as evidenced, different facets of a common underlying variable at a point in time.

To examine possible causal relationships, we estimate GMM_System Model (1) above, and report the results in Table 2. This table reports a base model in which some basic regressors are entered. Models for the full sample and for the OECD and non-OECD nations are estimated. The GMM_system estimations exhibit good statistical properties, but the OLS Model (3) is plagued by serial correlation. Random effects and fixed effects give substantively similar results in the full sample (Models 1 and 2, respectively), but the fixed effects models have relatively few observations per instrument, and we will focus in this investigation on the random effects models. Models for the OECD and non-OECD countries show some significant parameter heterogeneity, especially regarding the effects of trade integration; the effects of entry into the EU (new accession countries have lower corporate tax rates than older countries) also differ.

What is common in the results is a strong and highly statistically significant positive coefficient on our indicator of global ideological sentiment. As the vote share of the world's communist party decreased (increased) by 1 percent, corporate tax rates subsequently decreased (increased) by $3-5$ percent. Given the roughly $4 \frac{1}{2}$ point drop in communist party voting, the corresponding estimated drop in tax rates is in the 14-22 percent range.

Another result common across the models is the positive and highly statistically significant coefficient on global capital account openness. We argued earlier that increasing profit opportunities from global economic integration is likely to provide an incentive to countries to increase the tax rate on the resulting profits. This effect is substantively smaller than the ideology effect: a move from the lowest values of global capital account openness to the highest levels translates into a 6-12 percent increase in corporate tax rates. The home country capital account openness indicator is only statistically significant in the OLS estimates, which are contaminated by serial correlation.

Table 3 further explores parameter heterogeneity by dividing the samples into five groups: nonbanking OECD countries, wealthier emerging market countries, low-income emerging market countries, oil exporters, and banking centers. Sample shrinkage induces inefficiency in the estimates, but a comparison of the parameter estimates suggests that oil producers and banking center countries have processes that differ from the other groupings.

Table 4 explicitly tests the hypothesis that countries respond to the U.S. tax rate using the country groupings from Table 3 . Given the evidence in the scatterplots of a possible quadratic relationship between home country tax rates and the U.S. tax rate, we allow for the relationship to be quadratic by estimating the models with home-U.S. and home-U.S.squared variables.

The parameter estimates differ across the groupings. Because of the complexity of the relationship and the need to extract the covariances to calculate the standard errors, the 
results of Table 4 are presented in Figure $9 .{ }^{17}$ The dashed lines are the marginal effects of the home vs U.S. rate given by the parameter estimates (home-U.S. and home-U.S.-squared). The solid lines are the marginal effects that are statistically significant at the .05 level and beyond, once the covariance of $\mathrm{X}$ and $\mathrm{X}$-squared are accounted for.

The pattern of the main part of the relationship is found in the northwest and southeast quadrants, which was also the relationship found in the scatter plots. The statistically significant part of the relationships differs, however, across the sample. For the nonbanking OECD countries, large gaps above the U.S. corporate tax rate result in a subsequent drop. For example, a country (e.g., Sweden) with rates 20 points higher than the United States would be predicted to drop by 8 points over the United States in the subsequent period. There is modest scope for countries under the U.S. rate to increase in the subsequent period, though modestly. A country 15 points below the U.S. rate would be predicted to increase in the subsequent period by roughly 5 points. For emerging market nations, the curve accelerates down faster above the U.S. rate. For lower-income countries, only in ranges substantially below the U.S. rate is there any estimated effect. For many developing countries, capital income is one of the few tangible sources of government income.

Banking center countries have an estimated line mostly below zero. They do not raise taxes above the U.S. rate, though the line is not statistically significant in the ranges observed.

Table 5 explores the relationship between the share of corporate sector in value added and corporate taxes in an environment of financial globalization. Because of data limitation, the results of Table 5 cannot be compared strictly to the results of Table 4-the capital share data is too sparse for the oil, banking center, and lower-income countries. The models are full sample ( 1 and 2 ), non-OECD countries ( 3 and 4 ), and OECD countries (5 and 6 ). Interactions between capital account openness and capital share are estimated in Models 2 (full sample), 4 (non-OECD), and 6 (OECD). Importantly, the results in Table 5 account for the increasing inflows of nonresident investment (international liabilities) and outflows of resident investment (international assets) in the analysis.

OECD and non-OECD countries differ markedly in the parameter estimates. Among OECD, higher levels of the share of the corporate sector in a country's value added are associated with increasing corporate taxation (Model 5). We also investigated the extent to which the impact of capital share might be modified depending on international financial integration. However, the interaction term between capital share and capital account openness is not statistically significant. As an experiment, the impact of inequality on corporate taxation was also examined (for a measure of inequality, we used Gini coefficients with Dollar Kraay adjustments). The beta coefficient on the Gini was found to be positive and statistically significant beyond the .05 level (the model is not reported to save space). Thus among the OECD countries, higher levels of inequality or the share of corporate valued added in an economy are associated with higher levels of taxation.

\footnotetext{
${ }^{17}$ The marginal effect of $X$ on $Y$ from $X$ and $X^{2}$ are given by $\left(\beta_{1}+2 \beta_{2} X\right)$. The resulting standard error is given by the square root of $\left(\operatorname{var} \beta_{1}+4 \mathrm{X}^{2} \operatorname{var} \beta_{2}+4 \mathrm{X} \operatorname{covar}\left(\beta_{1} \theta_{2}\right)\right)$. See Friedrichs (1982).
} 
In contrast, in non-OECD countries, we see a statistically significant negative association between corporate value added in an economy and corporate tax rates, but the effect is relatively modest (Model 3). In a closed economy, a 10-point increase in capital share is associated with a 2-percent decrease in the corporate tax rates. But as a non-OECD economy becomes more financially open, the marginal effects of capital share diminish and turn positive. The statistically significant negative marginal effects of capital share are found only in the 0-55 range (out of 100) for capital account openness. In contrast, for a completely open emerging market economy (capital $=100$ ), the marginal effect of an increase in the corporate value added in the economy is positive and statistically significant, though modest: a 10percent increase in corporate value added is associated with a subsequent 0.7 -percent increase in the tax rates.

\section{CONClusions}

This paper has provided detailed empirical analysis of the impact of globalization on CT rates, particularly of financial integration, taking into account strategic considerations and a variety of other global and domestic political economy factors. The analysis, based on a unique and comprehensive sample of advanced, emerging, and low-income economies over the past five decades yields the following key results:

- $\quad$ There is no negative relationship between the extent of FG and corporate tax rates and revenues. Indeed, across some groups of OECD and non-OECD countries, an increase in FG is highly statistically significantly associated with a subsequent upward movement in corporate tax rates and revenues. This reflects both the impact of rising profitability attendant on globalization, and domestic political economy factors relating to desire for portfolio diversification by domestic corporate elites. However, the greater the trade openness, the lower the CT rates. At the same time, there is little evidence that overall higher global financial market integration leads to downward pressure on corporate tax rates.

- There is robust evidence of a form of "Stackelberg" leadership by the United States, whereby deviations from U.S. corporate tax rates, up or down, are not sustained over the longer term. In particular, rather than a race to the bottom, if rates are below those in the United States, there is a move toward the U.S. rates across a broad range of country groupings.

- We explore the dynamic effects of home vs. U.S. taxation for tax revenues, accounting for integration into the world economy (Appendix Table 1). For OECD countries, revenues increase with tax rate increases up until the increases exceed the U.S. rates, after which revenues attenuate. This is an area for further research.

- $\quad$ There is a clear role played by "global sentiment" relating to the role of markets and the corporate sector. This belief in the primacy of the markets (particularly since the collapse of the Soviet Union), has a direct bearing on private corporate sector and its tax treatment. Other things equal, this has exerted a clear downward influence on corporate tax rates (Figure 10). Global average tax rates on "immobile" factors (individuals) and "mobile" factors (corporations) have trended in the same direction 
and are very highly correlated: global forces beyond "strategic competition" are clearly at work. This is an area for further research.

- Domestic political economy factors play a key role. The corporate sector, particularly in closed emerging market economies, has a strong preference for lower tax rates, which suggests that the greater the role played by capital (and the greater concentration of capital) in production in a closed economy, the lower the rate of taxation. However, with openness, there is a diminution in the role of capital in the productive process (and diminished concentration). Further, firms and their owners have incentives, given openness, to seek diversified portfolios internationally, reducing the ability and incentive of domestic firms to push for lower rates. We believe that this is the first demonstration of the effects of capital share concentration on corporate tax policy in closed economies, and it is starkly at odds with standard views of the expected fate of "trapped" capital in closed economies.

- $\quad$ As seen in existing empirical studies, there is a positive relationship between government expenditures and corporate tax rates and collections: higher growth, presumably through a reduction in budgetary revenues, leads to subsequent lower CIT rates; and the smaller the population, ceteris paribus, the higher the rates.

These findings have a number of important implications. First, they underline the fact that the setting of CT rates is a more complex process than the simple competition model, or the "race to the bottom" framework in the context of increasing globalization might suggest. There are powerful domestic and global factors that each bear upon the setting of tax policy, as well as in concert with the financial globalization process. This is, of course, not to say that there are no empirical regularities regarding the determination of CTs, but rather that the process is richer and less straightforward than some of the literature suggests.

Second, globalization per se does not reduce the degree of policy maneuver. Conversely, any rolling back in the process of globalization would not effectively increase flexibility in the setting of CT rates. Third, in the aftermath of the global crisis and the severe budgetary pressures in most of the advanced economies, balancing of the various considerations is likely to make decision making regarding CIT rates even more difficult. But the evidence in this paper suggests that the role of U.S. policy would be crucial. Particularly given the budgetary pressures in the United States, were there to be an increase in the U.S. rate, it would allow some welcome flexibility to nudge rates higher in many other economies. On the other hand, however, were there to be any pronounced cuts in U.S. rates as is being debated currently, this is likely to have sizable adverse externalities for many economies, particularly those that are facing even larger fiscal pressures. 


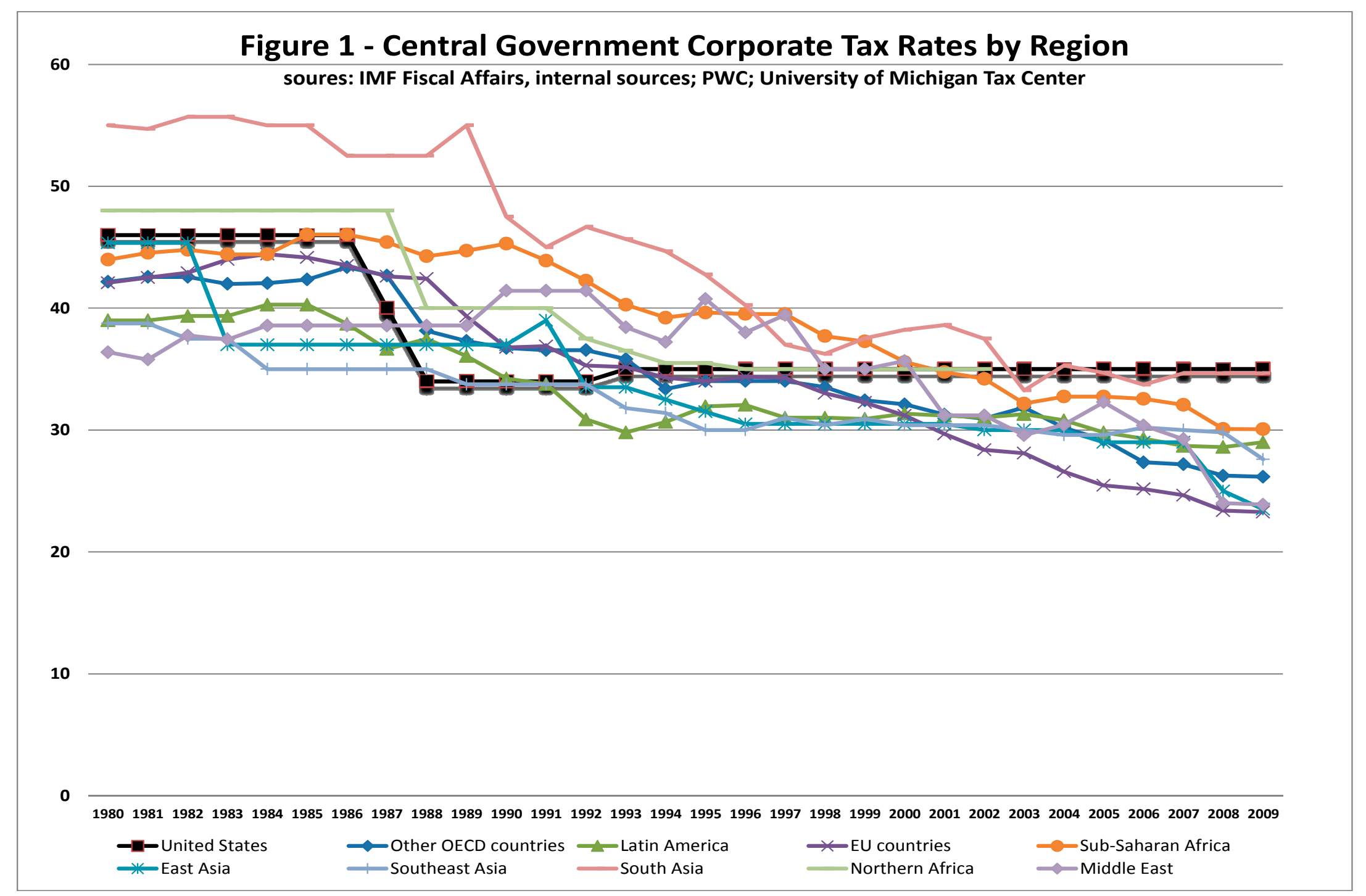




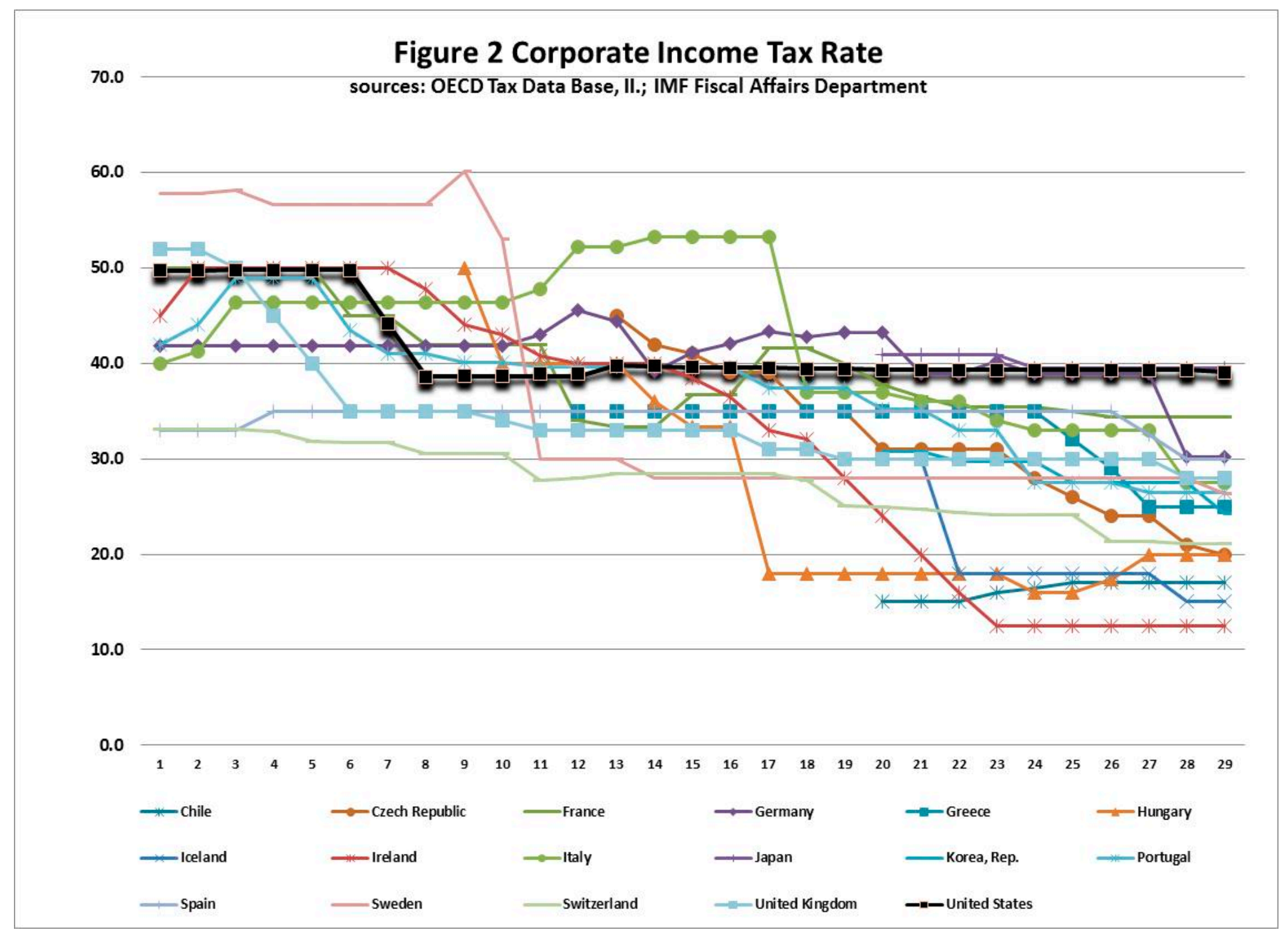

CInternational Monetary Fund. Not for Redistribution 


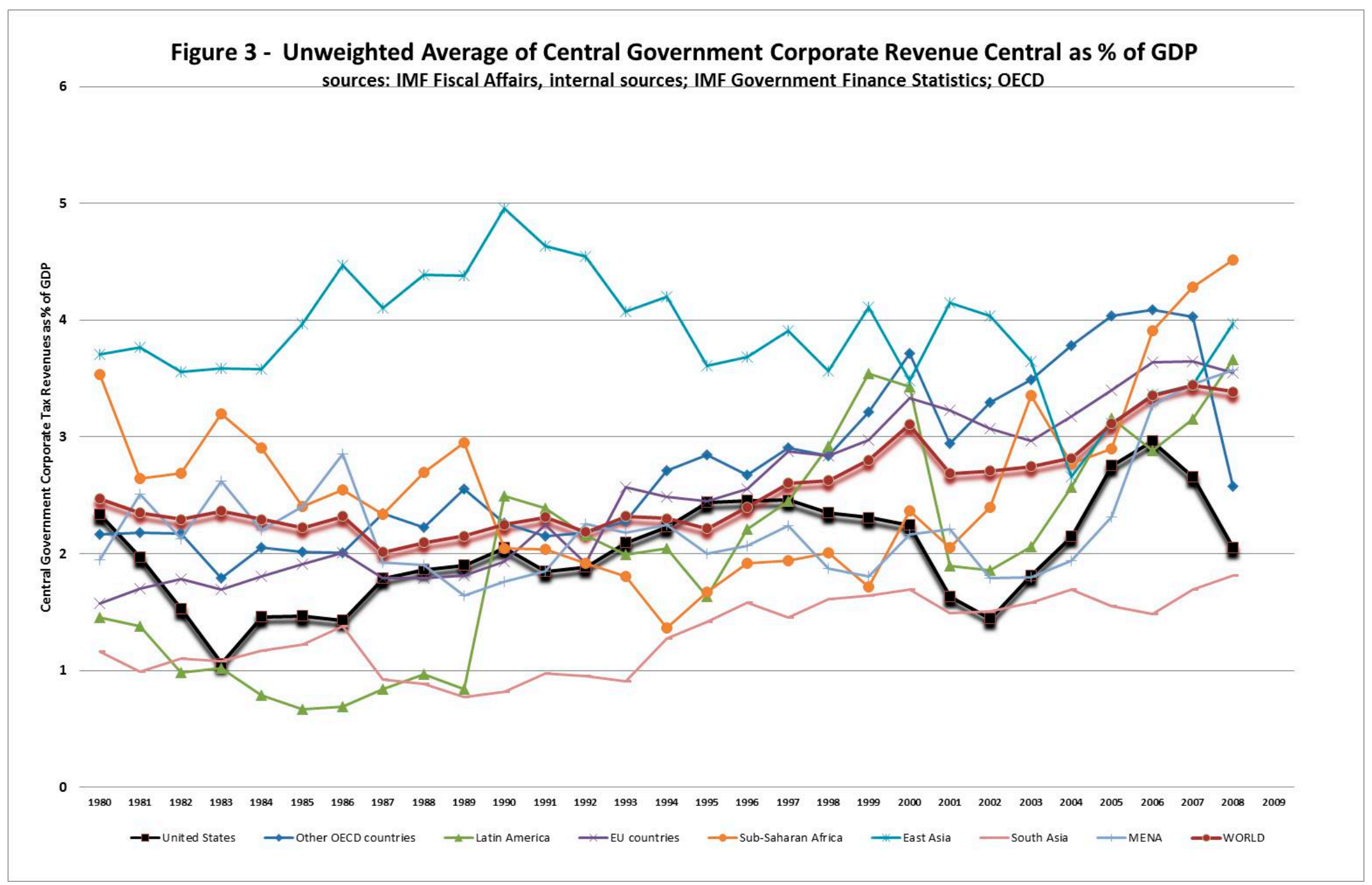




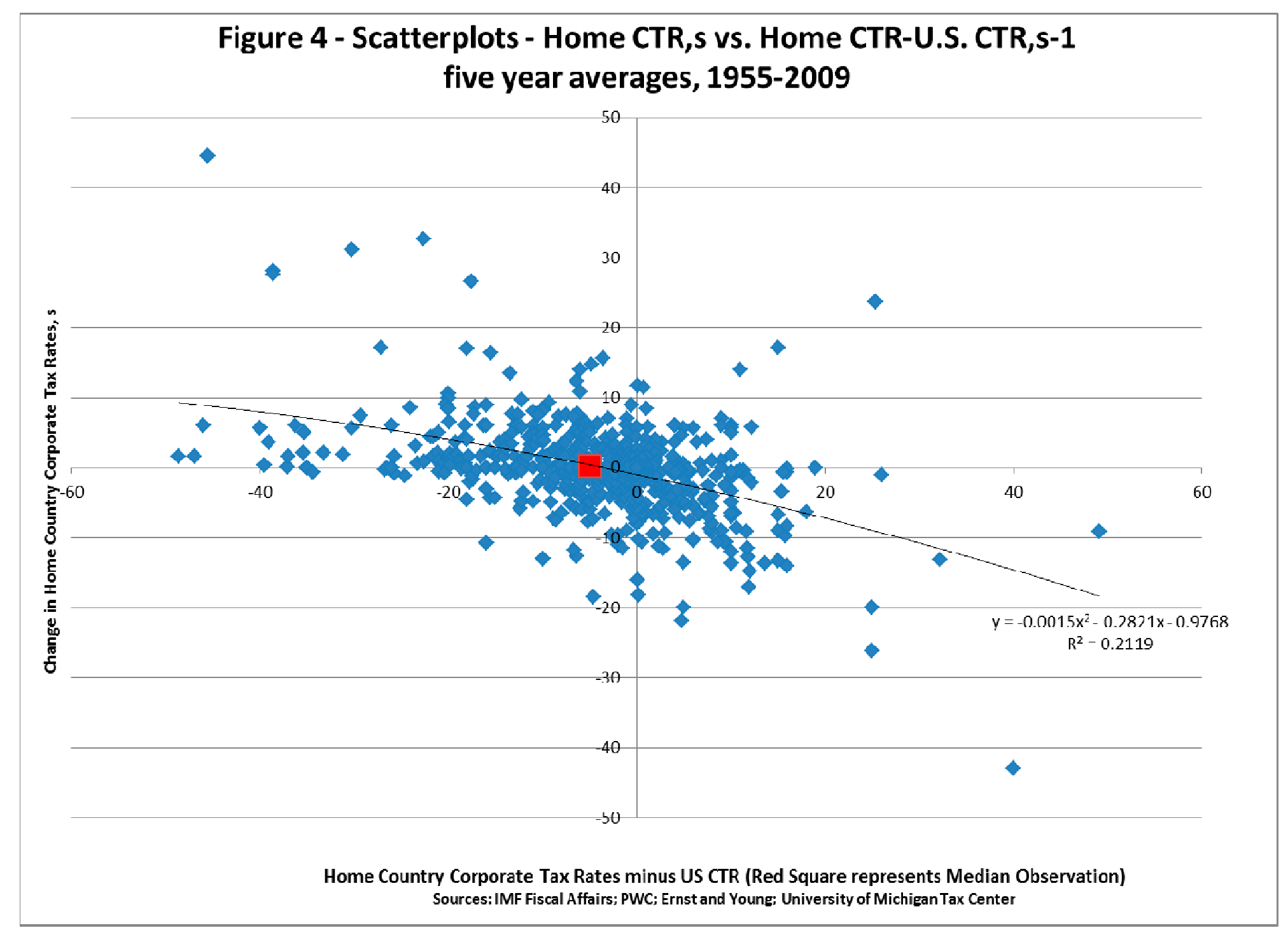




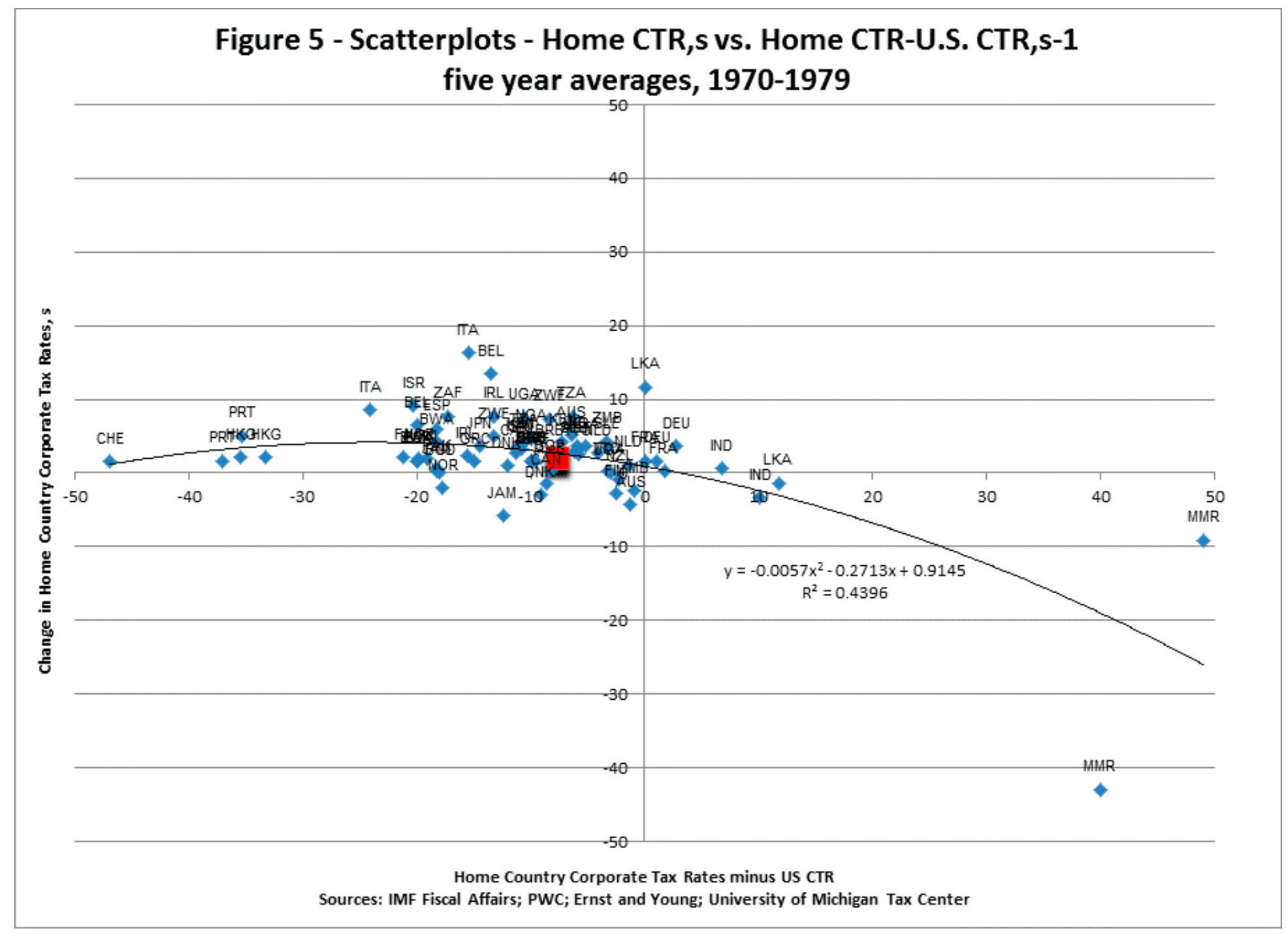




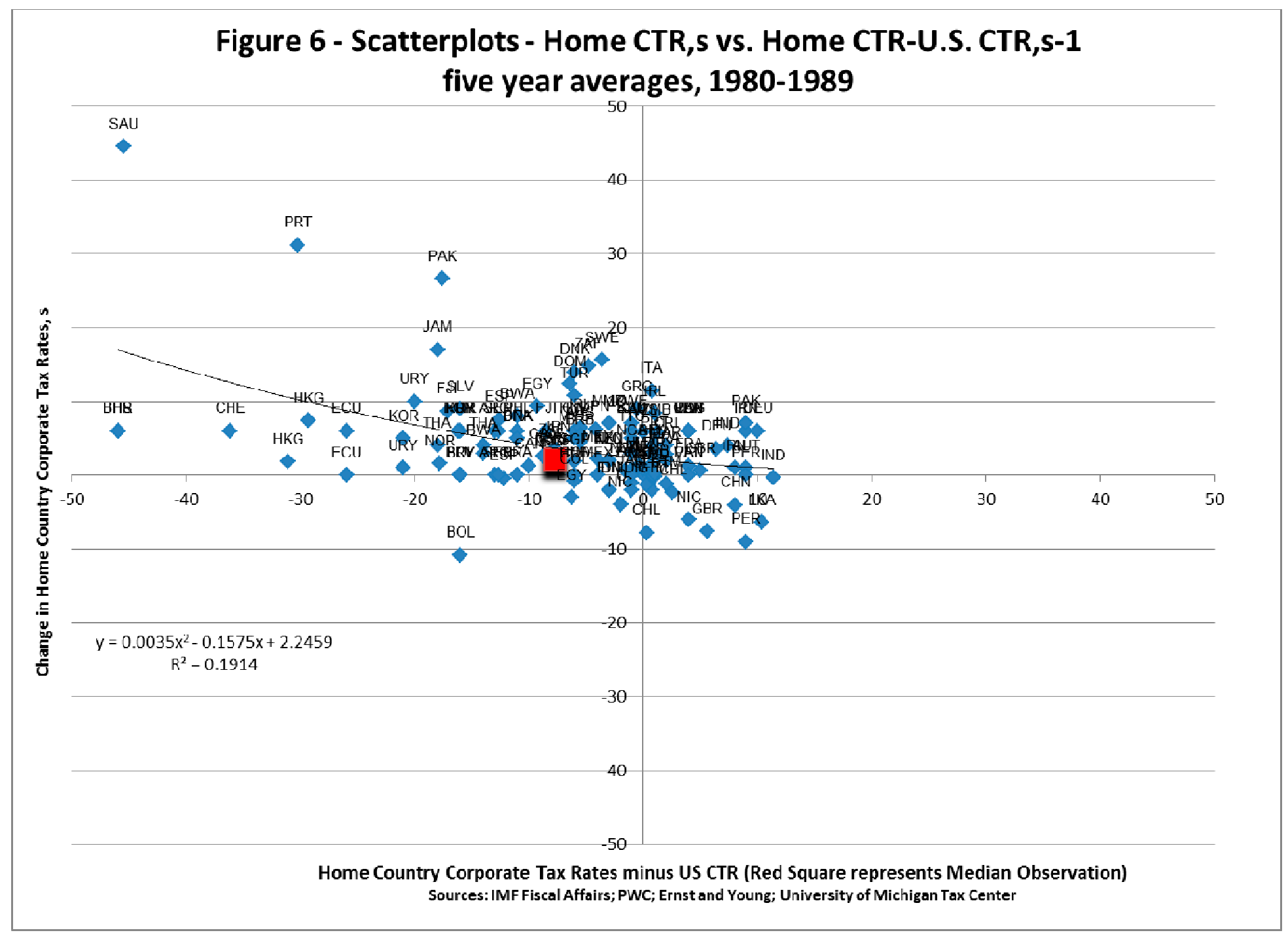




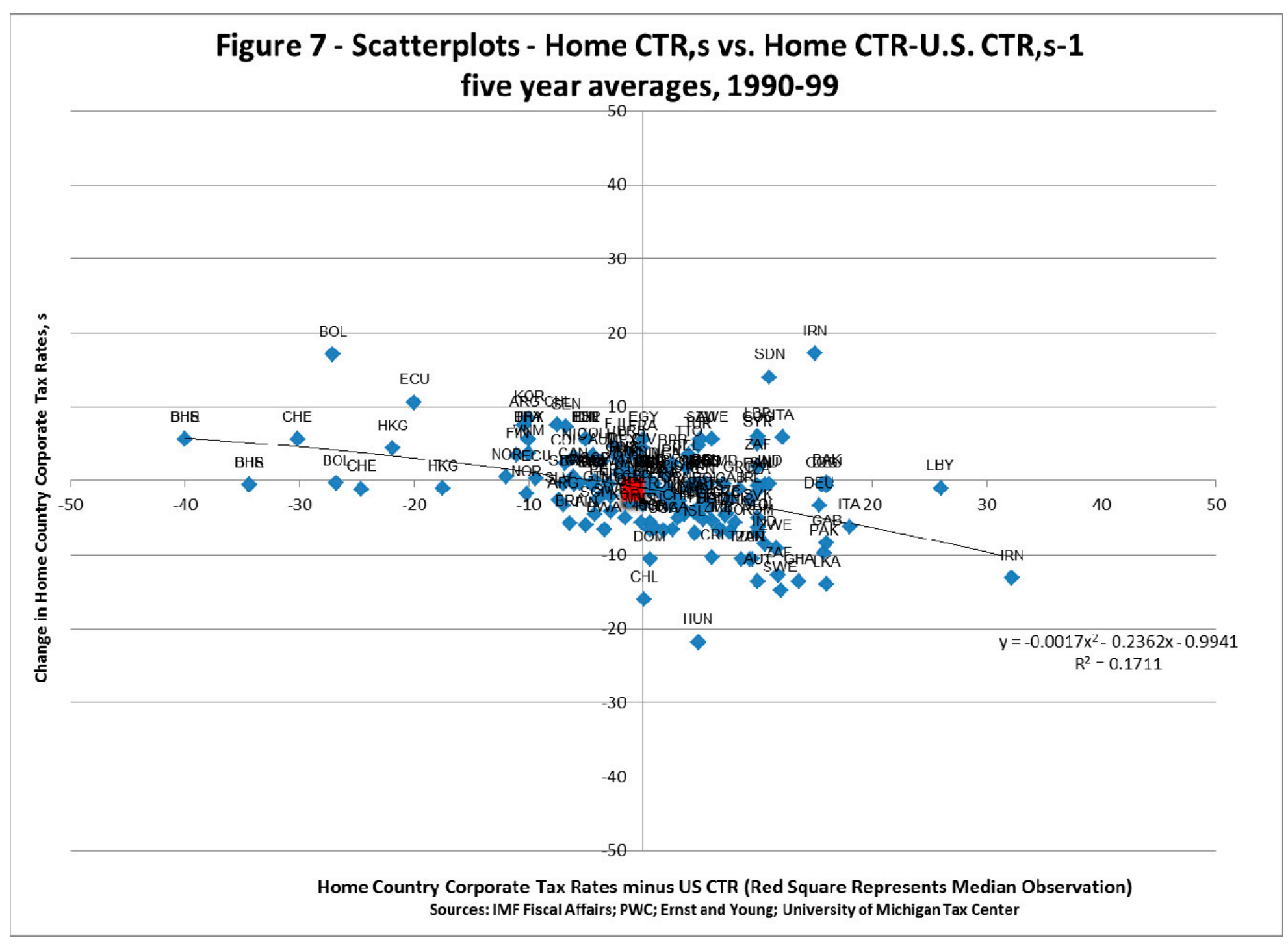




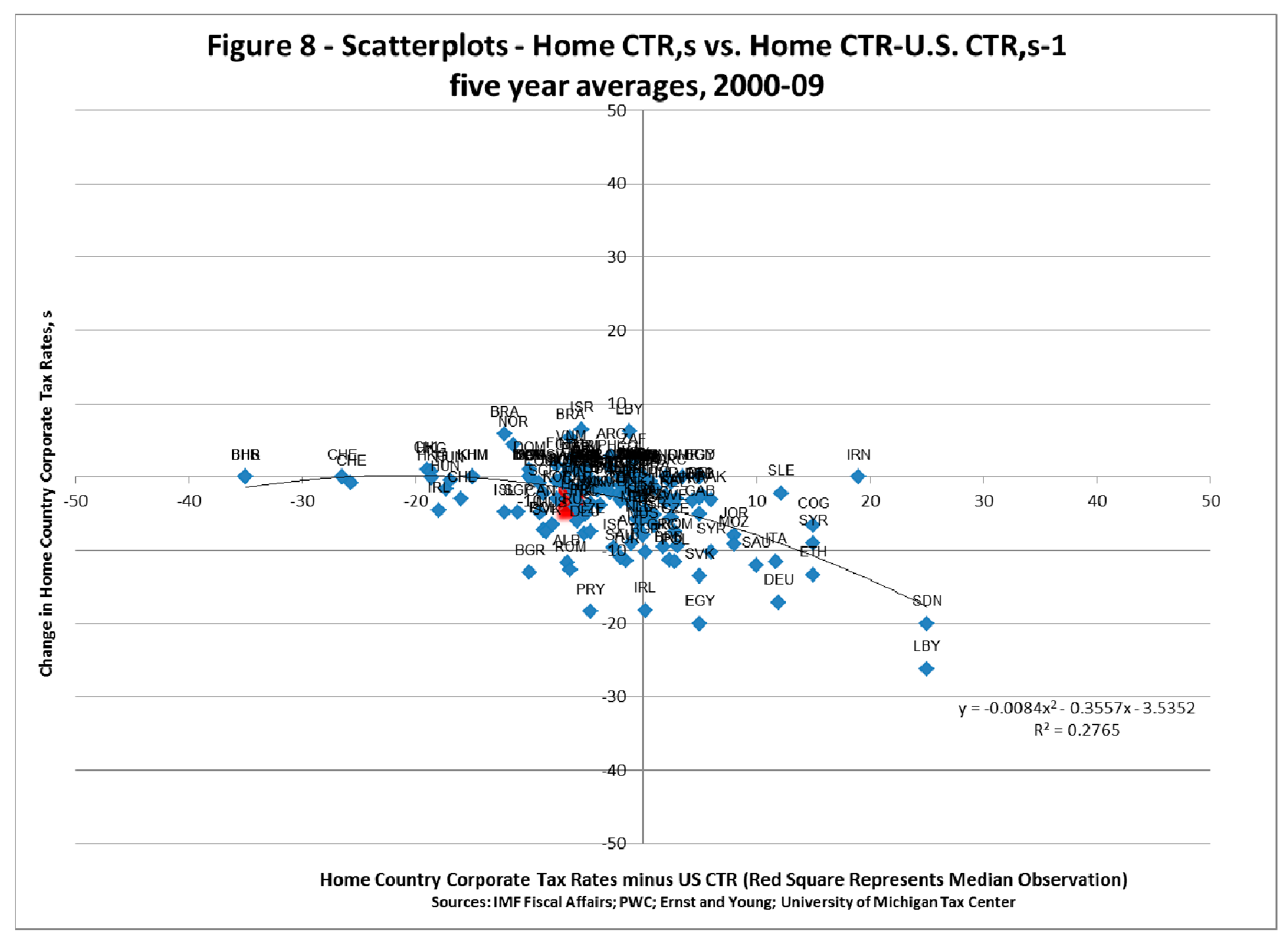




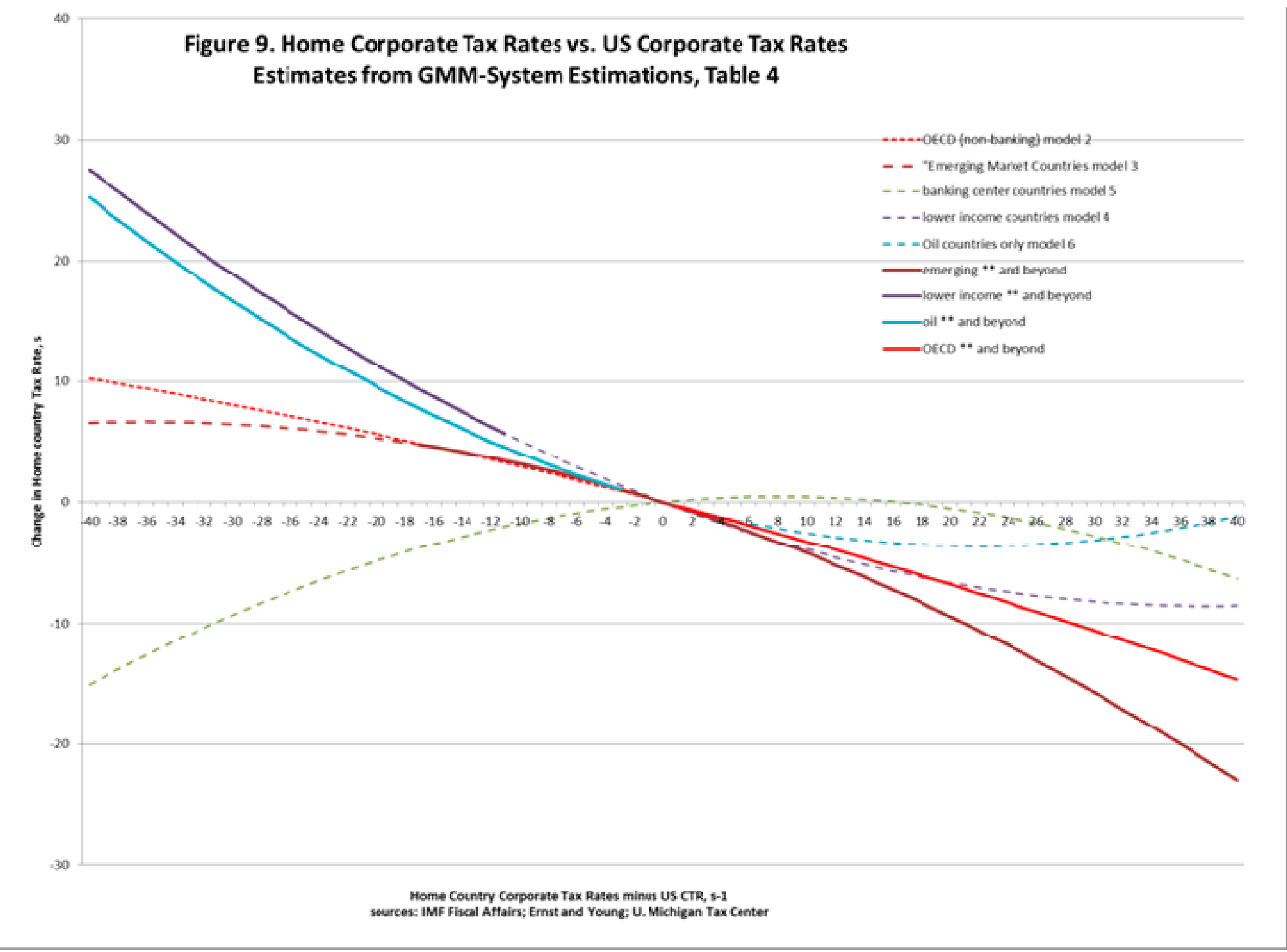


Figure 10 - Top Personal and Top Corporate Tax Rates

Unweighted Global Averages - 1981 to 2005

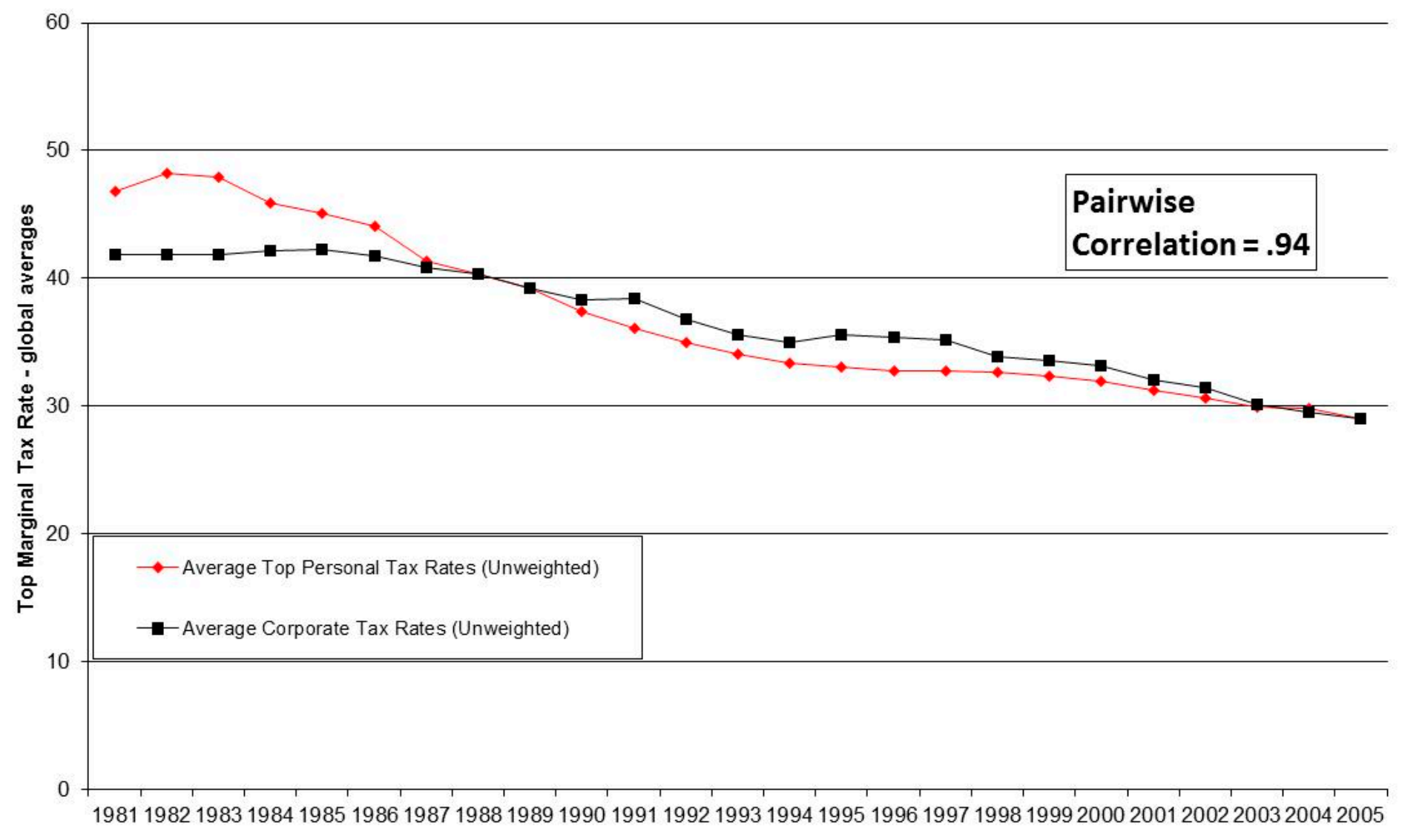

sources: corporate rates - see section V, this paper; personal rates - Peter, Buttrick, and Ducan 2010 
Table 1a. Factor Analysis of Regressors and Regressand

\begin{tabular}{|c|c|c|c|c|}
\hline & \multicolumn{4}{|c|}{ Component } \\
\hline & 1 & 2 & 3 & 4 \\
\hline Communist Vote & .931 & & & \\
\hline Global Capital & -.907 & & & \\
\hline Corp Tax Rate & .404 & & -.537 & \\
\hline Income PerCap & & .866 & & \\
\hline$\Delta$ Population & & -.797 & & \\
\hline Investment & & .708 & & \\
\hline Capital Openness & & .544 & & \\
\hline Trade Openness & & & .623 & \\
\hline grow6 & & & .595 & \\
\hline Gov Share & & & & .905 \\
\hline $\begin{array}{l}\text { TS Squared } \\
\text { Loadings }\end{array}$ & 2.8 & 2.05 & 1.08 & 1.03 \\
\hline$\%$ of Total Variance & 28 & 20.5 & 10.78 & 10.33 \\
\hline $\begin{array}{l}\text { Cumulative } \% \text { of } \\
\text { Variance }\end{array}$ & 28.0 & 48.49 & 59.3 & 69.61 \\
\hline $\begin{array}{l}\text { Descriptive Content } \\
\text { of Factor }\end{array}$ & $\begin{array}{l}\text { Global } \\
\text { Capital }\end{array}$ & Development & $\begin{array}{l}\text { Growth } \\
\text { Taxation }\end{array}$ & Government \\
\hline
\end{tabular}

Table 1b. Factor Analysis of Regressors and Regressand

\begin{tabular}{|c|c|c|c|c|}
\hline & \multicolumn{4}{|c|}{ Component } \\
\hline & 1 & 2 & 3 & 4 \\
\hline Income PerCap & .922 & & & \\
\hline$\Delta$ Population & -.729 & & & \\
\hline Investment & .710 & & & \\
\hline Financial Devel & .657 & & & \\
\hline Capital Openness & .632 & & & \\
\hline Int'| Assets & .553 & .811 & & \\
\hline Trade Openness & & .813 & & \\
\hline Int'I Liabilities & & .700 & & \\
\hline Corp Tax Rate & & -.548 & & \\
\hline Communist Vote & & & .928 & \\
\hline Global Capital & & & -.925 & \\
\hline grow6 & & & & .929 \\
\hline Gov Share & & & & \\
\hline $\begin{array}{l}\text { TS Squared } \\
\text { Loadings }\end{array}$ & 4.14 & 2.51 & 1.26 & 1.04 \\
\hline$\%$ of Total Variance & 31.8 & 19.3 & 9.67 & 8.0 \\
\hline $\begin{array}{l}\text { Cumulative \% of } \\
\text { Variance }\end{array}$ & 31.8 & 51.2 & 60.8 & 68.9 \\
\hline $\begin{array}{l}\text { Descriptive Content } \\
\text { of Factor }\end{array}$ & velopment & $\begin{array}{c}\text { Int'l } \\
\text { Integration }\end{array}$ & $\begin{array}{l}\text { Global } \\
\text { Capital }\end{array}$ & Growth \\
\hline
\end{tabular}

Notes: We use the "factor analysis" option in SPSS 19 with the varimax option, employing eigenvalues greater than 1 as the criterion for inclusion. Variables below the 0.4 threshold of statistical significance are not reported. 
Table 2. Determinants of Corporate Tax Rates: Full Sample, OECD and non-OECD

\begin{tabular}{|c|c|c|c|c|c|}
\hline Variable & $\begin{array}{l}\text { Model } 1 \\
\text { Full sample }\end{array}$ & $\begin{array}{l}\text { Model } 2 \\
\text { Full sample }\end{array}$ & $\begin{array}{l}\text { Model } 3 \\
\text { Full sample } \\
\text { OLS }\end{array}$ & $\begin{array}{l}\text { Model } 4 \\
\text { OECD }\end{array}$ & $\begin{array}{l}\text { Model } 5 \\
\text { nonOECD }\end{array}$ \\
\hline Capital Tax Rates (s-1) & $\begin{array}{l}0.807^{* * *} \\
(0.070)\end{array}$ & $\begin{array}{c}0.484^{\star \star *} \\
(0.069)\end{array}$ & $\begin{array}{c}0.523^{* * *} \\
(0.058)\end{array}$ & $\begin{array}{l}0.712^{* * *} \\
(0.077)\end{array}$ & $\begin{array}{l}0.749^{* * *} \\
(0.090)\end{array}$ \\
\hline Capital Tax Rates (s-2) & $\begin{array}{l}-0.065 \\
(0.053)\end{array}$ & $\begin{array}{l}-0.112^{* *} \\
(0.046)\end{array}$ & $\begin{array}{l}-0.111^{* * *} \\
(0.042)\end{array}$ & $\begin{array}{l}-0.061 \\
(0.059)\end{array}$ & $\begin{array}{l}-0.013 \\
(0.059)\end{array}$ \\
\hline$\triangle C A P I T A L(s-1)$ & $\begin{array}{l}-0.009 \\
(0.014)\end{array}$ & $\begin{array}{c}0.013 \\
(0.021)\end{array}$ & $\begin{array}{l}0.026 \\
(0.017)\end{array}$ & $\begin{array}{l}0.037 \\
0.043\end{array}$ & $\begin{array}{l}-0.005 \\
(0.019)\end{array}$ \\
\hline $\begin{array}{l}\Delta \text { Economic Growth } \\
(\mathrm{s}-1])\end{array}$ & $\begin{array}{l}-0.115 \\
(0.093)\end{array}$ & $\begin{array}{l}-0.168 \\
(0.106)\end{array}$ & $\begin{array}{l}-0.112 \\
(0.122)\end{array}$ & $\begin{array}{c}-1.057^{* * *} \\
(0.350)\end{array}$ & $\begin{array}{l}-0.004 \\
(0.257)\end{array}$ \\
\hline$\Delta$ Income $(\mathrm{s}-1)$ & $\begin{array}{l}-0.741^{* *} \\
(0.355)\end{array}$ & $\begin{array}{l}-0.417 \\
(1.736)\end{array}$ & $\begin{array}{l}-0.071 \\
(1.373)\end{array}$ & $\begin{array}{l}-1.018 \\
(2.453)\end{array}$ & $\begin{array}{l}-0.585 \\
(0.531)\end{array}$ \\
\hline $\begin{array}{l}\Delta \text { Investment (s-1) } \\
\text { (Share of GDP) }\end{array}$ & $\begin{array}{l}0.285 \\
(0.582)\end{array}$ & $\begin{array}{c}1.292 \\
(1.306)\end{array}$ & $\begin{array}{l}-0.776 \\
(1.064)\end{array}$ & $\begin{array}{c}3.846 \\
(2.982)\end{array}$ & $\begin{array}{l}-0.179 \\
(0.549)\end{array}$ \\
\hline $\begin{array}{l}\Delta \text { Government Share of } \\
\text { GDP (s-1) }\end{array}$ & $\begin{array}{l}-0.001 \\
(0.040)\end{array}$ & $\begin{array}{c}0.002 \\
(0.080)\end{array}$ & $\begin{array}{c}0.053 \\
(0.073)\end{array}$ & $\begin{array}{l}0.116 \\
(0.146)\end{array}$ & $\begin{array}{c}0.006 \\
(0.072)\end{array}$ \\
\hline$\Delta$ Trade Openness $(\mathrm{s}-1)$ & $\begin{array}{c}-0.949^{* * *} \\
(0.338)\end{array}$ & $\begin{array}{c}0.192 \\
(1.641)\end{array}$ & $\begin{array}{c}1.004 \\
(1.330)\end{array}$ & $\begin{array}{c}-3.014^{* * *} \\
(0.766)\end{array}$ & $\begin{array}{l}-0.950 \\
(0.907)\end{array}$ \\
\hline$\Delta$ Population(s-1) & $\begin{array}{l}0.338 \\
(0.403)\end{array}$ & $\begin{array}{l}-0.635 \\
(0.636)\end{array}$ & $\begin{array}{l}-0.110 \\
(0.619)\end{array}$ & $\begin{array}{l}2.006^{* *} \\
(0.997)\end{array}$ & $\begin{array}{c}0.488 \\
(0.867)\end{array}$ \\
\hline$\Delta$ Member of EU (s-1) & $\begin{array}{c}3.137^{* * *} \\
(1.074)\end{array}$ & $\begin{array}{c}1.877 \\
(1.813)\end{array}$ & $\begin{array}{c}1.571 \\
(1.183)\end{array}$ & $\begin{array}{c}5.475^{\star * *} \\
(1.758)\end{array}$ & $\begin{array}{l}-7.914^{*} \\
(4.608)\end{array}$ \\
\hline $\begin{array}{l}\Delta \text { World Communist } \\
\text { Party Vote Shares (s-1) }\end{array}$ & $\begin{array}{c}4.340^{* * *} \\
(0.681)\end{array}$ & $\begin{array}{c}4.387^{* * *} \\
(0.920)\end{array}$ & $\begin{array}{c}4.551^{* * *} \\
(0.706)\end{array}$ & $\begin{array}{c}3.128^{* * *} \\
(1.128)\end{array}$ & $\begin{array}{c}5.419^{* * *} \\
(1.222)\end{array}$ \\
\hline $\begin{array}{l}\Delta \text { World Average Global } \\
\text { Capital Openness }(s-1)\end{array}$ & $\begin{array}{l}0.382^{* * *} \\
(0.078)\end{array}$ & $\begin{array}{l}0.199^{* *} \\
(0.091)\end{array}$ & $\begin{array}{c}0.208^{* * *} \\
(0.067)\end{array}$ & $\begin{array}{l}0.244^{*} \\
(0.139)\end{array}$ & $\begin{array}{c}0.481^{* * *} \\
(0.136)\end{array}$ \\
\hline Fixed Effects & $\mathrm{n}$ & $\mathrm{y}$ & $\mathrm{y}$ & $\mathrm{n}$ & $\mathrm{n}$ \\
\hline r-square (=1-(rss/tss)) & 0.77 & 0.81 & 0.82 & 0.79 & 0.75 \\
\hline ABM1 & $\begin{array}{c}-3.577 \\
{[0.000]^{* *}}\end{array}$ & $\begin{array}{c}-3.386 \\
{[0.0001]^{\star *}}\end{array}$ & & $\begin{array}{c}-3.049 \\
{[0.002]^{\star *}}\end{array}$ & $\begin{array}{c}2.648 \\
{[0.008]^{* *}}\end{array}$ \\
\hline ABM2 & $\begin{array}{l}-1.361 \\
{[0.173]}\end{array}$ & $\begin{array}{l}-0.699 \\
{[0.484]}\end{array}$ & & $\begin{array}{l}-1.445 \\
{[0.148]}\end{array}$ & $\begin{array}{l}-1.538 \\
{[0.124]}\end{array}$ \\
\hline AR1 & & & $\begin{array}{l}-0.349 \\
{[0.727]}\end{array}$ & & \\
\hline AR2 & & & $\begin{array}{c}-2.856 \\
{[0.004]^{\star *}}\end{array}$ & & \\
\hline Number of Obs & 477 & 477 & 493 & 166 & 311 \\
\hline Countries & 86 & 86 & 94 & 22 & 64 \\
\hline Intercept & $\begin{array}{c}-21.906^{* *} \\
(8.64)\end{array}$ & $\begin{array}{l}-4.932 \\
(19.83)\end{array}$ & $\begin{array}{l}-12.446 \\
(15.37)\end{array}$ & $\begin{array}{c}-6.31 \\
(27.84)\end{array}$ & $\begin{array}{c}-32.62^{* * *} \\
(11.56)\end{array}$ \\
\hline
\end{tabular}


Table 3. Determinants of Corporate Tax Rates: OECD, Emerging and Developing Economies I

\begin{tabular}{|c|c|c|c|c|c|}
\hline Variable & $\begin{array}{c}\text { Model } 1 \\
\text { OECD, non } \\
\text { Banking center }\end{array}$ & $\begin{array}{c}\text { Model } 2 \\
\text { Emerging } \\
\text { Higher } \\
\text { income }\end{array}$ & $\begin{array}{l}\text { Model } 3 \\
\text { Low } \\
\text { Income }\end{array}$ & $\begin{array}{c}\text { Model } 4 \\
\text { Oil exporters }\end{array}$ & $\begin{array}{l}\text { Model } 5 \\
\text { Banking } \\
\text { centers }\end{array}$ \\
\hline Capital Tax Rates (s-1) & $\begin{array}{c}0.593^{* * *} \\
(0.05)\end{array}$ & $\begin{array}{c}0.571^{* * *} \\
(0.07)\end{array}$ & $\begin{array}{c}0.543^{* * *} \\
(0.05)\end{array}$ & $\begin{array}{c}0.551^{* * *} \\
(0.15)\end{array}$ & $\begin{array}{c}0.924^{\star \star \star} \\
(0.08)\end{array}$ \\
\hline Capital Tax Rates (s-2) & & & & & $\begin{array}{l}-0.023 \\
(0.095)\end{array}$ \\
\hline$\triangle C A P I T A L(s-1)$ & $-0.025 \quad 0.031$ & $\begin{array}{l}-0.016 \\
0.042\end{array}$ & $\begin{array}{l}0.038 \\
0.028\end{array}$ & $\begin{array}{c}-0.094^{\star *} \\
0.045\end{array}$ & $\begin{array}{l}-0.01 \\
(0.013\end{array}$ \\
\hline $\begin{array}{l}\Delta \text { Economic Growth } \\
(\mathrm{s}-1])\end{array}$ & $\begin{array}{c}-0.642^{* *} \\
(0.29)\end{array}$ & $\begin{array}{l}-0.174 \\
(0.15)\end{array}$ & $\begin{array}{c}-0.202^{*} \\
(0.12)\end{array}$ & $\begin{array}{l}0.015 \\
(0.31)\end{array}$ & $\begin{array}{l}-0.498 \\
(0.37)\end{array}$ \\
\hline$\Delta$ Income (s-1) & $\begin{array}{l}2.233 \\
(2.00)\end{array}$ & $\begin{array}{c}0.85 \\
(1.00)\end{array}$ & $\begin{array}{l}0.269 \\
(0.99)\end{array}$ & $\begin{array}{l}2.11^{*} \\
(0.85)\end{array}$ & $\begin{array}{l}-0.386 \\
(1.97)\end{array}$ \\
\hline $\begin{array}{l}\Delta \text { Investment (s-1) } \\
\text { (Share of GDP) }\end{array}$ & $\begin{array}{l}5.171^{*} \\
(2.73)\end{array}$ & $\begin{array}{l}-0.082 \\
(0.65)\end{array}$ & $\begin{array}{c}0.64 \\
(1.00)\end{array}$ & $\begin{array}{c}3.32 \\
(2.23)\end{array}$ & $\begin{array}{l}0.254 \\
(0.79)\end{array}$ \\
\hline $\begin{array}{l}\Delta \text { Government Share of } \\
\text { GDP }(\mathrm{s}-1)\end{array}$ & $\begin{array}{l}0.037 \\
(0.09)\end{array}$ & $\begin{array}{l}-0.031 \\
(0.08)\end{array}$ & $\begin{array}{c}0.154^{* * *} \\
(0.04)\end{array}$ & $\begin{array}{l}-0.182 \\
(0.17)\end{array}$ & $\begin{array}{l}-0.010 \\
(0.10)\end{array}$ \\
\hline$\Delta$ Trade Openness(s-1) & $\begin{array}{c}-2.911^{* * *} \\
(0.77)\end{array}$ & $\begin{array}{l}0.301 \\
(0.42)\end{array}$ & $\begin{array}{l}-2.35^{*} \\
(1.12)\end{array}$ & $\begin{array}{l}-0.837 \\
(1.28)\end{array}$ & $\begin{array}{l}-0.819 \\
(1.72)\end{array}$ \\
\hline$\Delta$ Population(s-1) & $\begin{array}{c}2.123^{* *} \\
(1.07)\end{array}$ & $\begin{array}{l}1.084^{*} \\
(0.70)\end{array}$ & $\begin{array}{l}0.954 \\
(0.61)\end{array}$ & $\begin{array}{l}2.39^{*} \\
(0.95)\end{array}$ & $\begin{array}{l}0.365 \\
(1.04)\end{array}$ \\
\hline$\Delta$ Member of EU (s-1) & $\begin{array}{c}5.956^{* * *} \\
(1.37)\end{array}$ & $\begin{array}{r}-11.23^{*} \\
(4.76)\end{array}$ & & & $\begin{array}{l}-0.64 \\
(1.83)\end{array}$ \\
\hline $\begin{array}{l}\Delta \text { WorldCommunistParty } \\
\text { VoteShares }(\mathrm{s}-1)\end{array}$ & $\begin{array}{c}3.148^{* * *} \\
(0.85)\end{array}$ & $\begin{array}{l}3.59^{* * *} \\
(1.14)\end{array}$ & $\begin{array}{c}4.75^{\star \star *} \\
(1.23)\end{array}$ & $\begin{array}{l}2.90^{*} \\
(1.52)\end{array}$ & $\begin{array}{l}3.94^{* * *} \\
(0.93)\end{array}$ \\
\hline $\begin{array}{l}\Delta \text { WorldAverageGlobal } \\
\text { CapitalOpenness }(\mathrm{s}-1)\end{array}$ & $\begin{array}{l}0.133 \\
(0.12)\end{array}$ & $\begin{array}{l}0.264 \\
(0.23)\end{array}$ & $\begin{array}{l}0.277 \\
(0.20)\end{array}$ & $\begin{array}{l}0.282 \\
(0.18)\end{array}$ & $\begin{array}{l}0.240^{*} \\
(0.09)\end{array}$ \\
\hline r-square $(=1-($ rss/tss $))$ & 0.73 & 0.58 & 0.61 & 0.67 & 0.94 \\
\hline ABM1 & $\begin{array}{c}-3.142 \\
{[0.002]^{\star *}}\end{array}$ & $\begin{array}{c}-2.278 \\
{[0.023]^{*}}\end{array}$ & $\begin{array}{l}-1.343 \\
{[0.179]}\end{array}$ & $\begin{array}{l}-1.657 \\
{[0.097]}\end{array}$ & $\begin{array}{l}-1.201 \\
{[0.229]}\end{array}$ \\
\hline ABM2 & $\begin{array}{c}-0.580 \\
{[0.561]}\end{array}$ & $\begin{array}{l}-1.342 \\
{[0.179]}\end{array}$ & $\begin{array}{c}-0.91 \\
{[0.275]}\end{array}$ & $\begin{array}{l}-0.085 \\
{[0.93]}\end{array}$ & $\begin{array}{l}-0.358 \\
{[0.72]}\end{array}$ \\
\hline Number of Obs & 174 & 190 & 108 & 48 & 46 \\
\hline Countries & 20 & 36 & 21 & 8 & 8 \\
\hline Intercept & $\begin{array}{l}-35.10^{*} \\
(22.88)\end{array}$ & $\begin{array}{c}-25.075 \\
(24.54)\end{array}$ & $\begin{array}{l}-18.94 \\
(19.99)\end{array}$ & $\begin{array}{l}-31.35^{*} \\
(14.51)\end{array}$ & $\begin{array}{l}-19.90 \\
(25.58)\end{array}$ \\
\hline
\end{tabular}


Table 4. Determinants of Corporate Tax Rates: OECD, Emerging and Developing Economies II

\begin{tabular}{|c|c|c|c|c|c|c|}
\hline Variable & $\begin{array}{l}\text { Model } 1 \\
\text { Full sample }\end{array}$ & $\begin{array}{l}\text { Model } 2 \\
\text { OECD non } \\
\text { Bank }\end{array}$ & $\begin{array}{l}\text { Model } 3 \\
\text { emerging }\end{array}$ & $\begin{array}{c}\text { Model } 4 \\
\text { Low income }\end{array}$ & $\begin{array}{l}\text { Model } 5 \\
\text { banking }\end{array}$ & $\begin{array}{c}\text { Model } 6 \\
\text { Oil }\end{array}$ \\
\hline Capital Tax Rates (s-1) & $\begin{array}{c}0.858^{\star \star \star *} \\
(0.129)\end{array}$ & $\begin{array}{c}0.865^{* * *} \\
(0.162)\end{array}$ & $\begin{array}{c}0.909^{* * *} \\
(0.082)\end{array}$ & $\begin{array}{l}1.087^{\star \star \star} \\
(0.278)\end{array}$ & $\begin{array}{l}0.549^{*} \\
(0.303)\end{array}$ & $\begin{array}{l}1.010^{\star \star \star} \\
(0.250)\end{array}$ \\
\hline Capital Tax Rates (s-2) & $\begin{array}{l}-0.06 \\
(0.054)\end{array}$ & $\begin{array}{l}-0.089 \\
(0.064)\end{array}$ & & $\begin{array}{l}-0.037 \\
(0.087)\end{array}$ & & \\
\hline $\begin{array}{l}\text { Home Capital Tax Rates } \\
\text { minus U.S. Capital Tax } \\
\text { Rates (s-1) }\end{array}$ & $\begin{array}{l}-0.078 \\
(0.13)\end{array}$ & $\begin{array}{c}-0.311^{*} \\
(0.16)\end{array}$ & $\begin{array}{c}-0.389^{* * *} \\
(0.104)\end{array}$ & $\begin{array}{l}-0.451 \\
(0.303)\end{array}$ & $\begin{array}{l}0.109 \\
(0.315)\end{array}$ & $\begin{array}{l}-0.329^{*} \\
(0.185)\end{array}$ \\
\hline $\begin{array}{l}\text { Home Capital Tax Rates } \\
\text { minus U.S. Capital Tax } \\
\text { Rates SQUARED (s-1) }\end{array}$ & $\begin{array}{l}-0.001 \\
(0.001)\end{array}$ & $\begin{array}{l}-0.001 \\
(0.002)\end{array}$ & $\begin{array}{l}-0.005 \\
(0.004)\end{array}$ & $\begin{array}{l}0.005^{* *} \\
(0.002)\end{array}$ & $\begin{array}{c}-0.006^{* * *} \\
(0.001)\end{array}$ & $\begin{array}{l}0.007^{* *} \\
(0.003)\end{array}$ \\
\hline$\triangle C A P I T A L(s-1)$ & $\begin{array}{l}-0.006 \\
(0.013)\end{array}$ & $\begin{array}{l}-0.007 \\
(0.031)\end{array}$ & $\begin{array}{l}-0.008 \\
(0.017)\end{array}$ & $\begin{array}{l}0.024 \\
(0.018)\end{array}$ & $\begin{array}{l}-0.021 \\
(0.022)\end{array}$ & $\begin{array}{l}-0.035 \\
(0.033)\end{array}$ \\
\hline $\begin{array}{l}\Delta \text { Economic Growth } \\
(\mathrm{s}-1])\end{array}$ & $\begin{array}{l}-0.106 \\
(0.093)\end{array}$ & $\begin{array}{c}-0.968^{* * *} \\
(0.364)\end{array}$ & $\begin{array}{l}-0.05 \\
(0.166)\end{array}$ & $\begin{array}{c}-0.315^{\star * *} \\
(0.098)\end{array}$ & $\begin{array}{l}-0.312 \\
(0.246)\end{array}$ & $\begin{array}{l}-0.210 \\
(0.345)\end{array}$ \\
\hline$\Delta$ Income $(\mathrm{s}-1)$ & $\begin{array}{l}-0.761^{* *} \\
(0.347)\end{array}$ & $\begin{array}{c}0.440 \\
(1.767)\end{array}$ & $\begin{array}{c}0.57 \\
(0.791)\end{array}$ & $\begin{array}{l}0.180 \\
(0.773)\end{array}$ & $\begin{array}{l}-1.558^{*} \\
(0.900)\end{array}$ & $\begin{array}{l}1.11^{* *} \\
(0.42)\end{array}$ \\
\hline $\begin{array}{l}\Delta \text { Investment }(\mathrm{s}-1) \\
(\text { Share of GDP) }\end{array}$ & $\begin{array}{l}0.155 \\
(0.605)\end{array}$ & $\begin{array}{c}2.76 \\
(3.068)\end{array}$ & $\begin{array}{l}-0.004 \\
(0.845)\end{array}$ & $\begin{array}{l}0.243 \\
(0.715)\end{array}$ & $\begin{array}{l}-0.566 \\
(0.818)\end{array}$ & $\begin{array}{c}2.137 \\
(1.777)\end{array}$ \\
\hline $\begin{array}{l}\Delta \text { Government Share of } \\
\text { GDP }(\mathrm{s}-1)\end{array}$ & $\begin{array}{l}0.007 \\
(0.04)\end{array}$ & $\begin{array}{l}-0.096 \\
(0.109)\end{array}$ & $\begin{array}{l}-0.013 \\
(0.054)\end{array}$ & $\begin{array}{l}0.110 \\
(0.078)\end{array}$ & $\begin{array}{l}-0.081 \\
(0.049)\end{array}$ & $\begin{array}{l}-0.194 \\
(0.136)\end{array}$ \\
\hline$\Delta$ Trade Openness(s-1) & $\begin{array}{c}-1.007^{\star * *} \\
(0.325)\end{array}$ & $\begin{array}{c}-2.713^{\star * *} \\
(0.795)\end{array}$ & $\begin{array}{c}0.166 \\
(0.418)\end{array}$ & $\begin{array}{l}-1.415 \\
(1.314)\end{array}$ & $\begin{array}{l}-2.836 \\
(1.789)\end{array}$ & $\begin{array}{c}0.025 \\
(1.402)\end{array}$ \\
\hline$\Delta$ Member of EU (s-1) & $\begin{array}{c}3.307^{* * *} \\
(0.91)\end{array}$ & $\begin{array}{l}5.884^{* * *} \\
(1.096)\end{array}$ & $\begin{array}{c}-14.231^{* * *} \\
(4.111)\end{array}$ & & & \\
\hline $\begin{array}{l}\Delta \text { WorldCommunistPartyV } \\
\text { oteShares }(0,1)\end{array}$ & $\begin{array}{c}3.936^{* * *} \\
(1.118)\end{array}$ & $\begin{array}{c}1.961 \\
(1.511)\end{array}$ & & $\begin{array}{c}1.655 \\
(1.478)\end{array}$ & $\begin{array}{c}3.139 \\
(3.571)\end{array}$ & $\begin{array}{c}0.565 \\
(1.994)\end{array}$ \\
\hline $\begin{array}{l}\Delta \text { WorldAverageGlobal } \\
\text { CapitalOpenness }(0,1)\end{array}$ & $\begin{array}{l}0.36^{* * *} \\
(0.089)\end{array}$ & $\begin{array}{c}0.120 \\
(0.137)\end{array}$ & & $\begin{array}{c}0.112 \\
(0.189)\end{array}$ & $\begin{array}{c}0.007 \\
(0.301)\end{array}$ & $\begin{array}{c}0.136 \\
(0.204)\end{array}$ \\
\hline r-square $(=1-($ rss/tss $))$ & 0.77 & 0.74 & 0.57 & 0.71 & 0.96 & 0.72 \\
\hline ABM1 & $\begin{array}{c}-3.736 \\
{[0.000]^{* *}}\end{array}$ & $\begin{array}{c}-2.741 \\
{[0.006]^{\star *}}\end{array}$ & $\begin{array}{c}-2.498 \\
{[0.012]}\end{array}$ & $\begin{array}{c}-1.998 \\
{[0.046]^{*}}\end{array}$ & $\begin{array}{l}-1.144 \\
{[0.252]}\end{array}$ & $\begin{array}{l}-1.669 \\
{[0.095]}\end{array}$ \\
\hline ABM2 & $\begin{array}{l}-1.479 \\
{[0.139]}\end{array}$ & $\begin{array}{l}-1.459 \\
{[0.145]}\end{array}$ & $\begin{array}{l}-1.563 \\
{[0.118]}\end{array}$ & $\begin{array}{l}-1.585 \\
{[0.113]}\end{array}$ & $\begin{array}{l}-0.289 \\
{[0.772]}\end{array}$ & $\begin{array}{c}0.045 \\
{[0.964]}\end{array}$ \\
\hline Number of Obs & 477 & 152 & 190 & 84 & 53 & 48 \\
\hline Countries & 86 & 20 & 36 & 16 & 8 & 8 \\
\hline Intercept & $\begin{array}{c}-20.951^{* * *} \\
(8.012)\end{array}$ & $\begin{array}{c}-10.99 \\
(23.200)\end{array}$ & $\begin{array}{l}-7.035 \\
(6.733)\end{array}$ & $\begin{array}{l}-15.242 \\
(21.570)\end{array}$ & $\begin{array}{c}32.655 \\
(31.190)\end{array}$ & $\begin{array}{l}-25.039 \\
(14.030\end{array}$ \\
\hline
\end{tabular}


Table 5. Corporate Taxation, Capital Share and Countries' Net Asset Position

\begin{tabular}{|c|c|c|c|c|c|c|}
\hline & $\begin{array}{c}\text { Model } 1 \\
\text { Full sample }\end{array}$ & $\begin{array}{c}\text { Model } 2 \\
\text { Full sample }\end{array}$ & $\begin{array}{c}\text { Model } 3 \\
\text { nonOECD }\end{array}$ & $\begin{array}{l}\text { Model } 4 \\
\text { nonOECD }\end{array}$ & $\begin{array}{l}\text { Model } 5 \\
\text { OECD }\end{array}$ & $\begin{array}{l}\text { Model } 6 \\
\text { OECD }\end{array}$ \\
\hline Capital Tax Rates (s-1) & $\begin{array}{l}0.665^{* * *} \\
(0.045)\end{array}$ & $\begin{array}{l}0.670^{* * *} \\
(0.044)\end{array}$ & $\begin{array}{l}0.713^{* * *} \\
(0.039)\end{array}$ & $\begin{array}{l}0.724^{* * *} \\
(0.034)\end{array}$ & $\begin{array}{l}0.450^{* * *} \\
(0.086)\end{array}$ & $\begin{array}{l}0.450^{* * *} \\
(0.086)\end{array}$ \\
\hline$\Delta$ Capital Share $(s-1)$ & $\begin{array}{l}-0.054^{*} \\
(0.031)\end{array}$ & $\begin{array}{l}-0.157^{* *} \\
(0.063)\end{array}$ & $\begin{array}{l}-0.068^{*} \\
(0.037)\end{array}$ & $\begin{array}{l}-0.195^{\star * *} \\
(0.058)\end{array}$ & $\begin{array}{l}0.177^{* *} \\
(0.081)\end{array}$ & $\begin{array}{c}0.206 \\
(0.726)\end{array}$ \\
\hline$\Delta$ Capital Openness (s-1) & $\begin{array}{l}-0.000 \\
(0.014)\end{array}$ & $\begin{array}{l}-0.120^{*} \\
(0.069)\end{array}$ & $\begin{array}{l}-0.006 \\
(0.017)\end{array}$ & $\begin{array}{c}-0.196^{* * *} \\
(0.064)\end{array}$ & $\begin{array}{l}-0.004 \\
(0.071)\end{array}$ & $\begin{array}{c}0.012 \\
(0.379)\end{array}$ \\
\hline $\begin{array}{l}\Delta \text { Capital Openness }(s- \\
1)^{*} \Delta \text { Capital Share }(s-1)\end{array}$ & & $\begin{array}{l}0.002^{*} \\
(0.001)\end{array}$ & & $\begin{array}{l}0.003^{* * *} \\
(0.001)\end{array}$ & & $\begin{array}{l}-0.000 \\
(0.009)\end{array}$ \\
\hline $\begin{array}{l}\Delta \text { Economic Growth } \\
(\mathrm{s}-1])\end{array}$ & $\begin{array}{l}-0.136 \\
(0.118)\end{array}$ & $\begin{array}{l}-0.120 \\
(0.123)\end{array}$ & $\begin{array}{l}-0.083 \\
(0.118)\end{array}$ & $\begin{array}{l}-0.048 \\
(0.121)\end{array}$ & $\begin{array}{l}-0.454^{*} \\
(0.248)\end{array}$ & $\begin{array}{l}-0.454^{*} \\
(0.249)\end{array}$ \\
\hline$\Delta$ Income (s-1) & $\begin{array}{l}-0.853 \\
(0.572)\end{array}$ & $\begin{array}{l}-0.836 \\
(0.583)\end{array}$ & $\begin{array}{l}-0.401 \\
(0.537)\end{array}$ & $\begin{array}{c}0.379 \\
(0.549)\end{array}$ & $\begin{array}{c}4.308 \\
(6.281)\end{array}$ & $\begin{array}{c}4.423 \\
(8.694)\end{array}$ \\
\hline $\begin{array}{l}\Delta \text { Investment }(\mathrm{s}-1) \\
(\text { Share of GDP) }\end{array}$ & $\begin{array}{l}1.558^{* *} \\
(0.629)\end{array}$ & $\begin{array}{l}1.593^{* *} \\
(0.644)\end{array}$ & $\begin{array}{l}1.697^{* *} \\
(0.800)\end{array}$ & $\begin{array}{l}1.608^{* *} \\
(0.791)\end{array}$ & $\begin{array}{l}-4.008 \\
(3.087)\end{array}$ & $\begin{array}{l}-4.118 \\
(4.630)\end{array}$ \\
\hline $\begin{array}{l}\Delta \text { Government Share of GDP } \\
(\mathrm{s}-1)\end{array}$ & $\begin{array}{l}-0.027 \\
(0.044)\end{array}$ & $\begin{array}{l}-0.024 \\
(0.044)\end{array}$ & $\begin{array}{l}-0.013 \\
(0.037)\end{array}$ & $\begin{array}{l}-0.019 \\
(0.037)\end{array}$ & $\begin{array}{c}0.058 \\
(0.146)\end{array}$ & $\begin{array}{c}0.056 \\
(1.244)\end{array}$ \\
\hline$\Delta$ Trade Openness(s-1) & $\begin{array}{l}-0.946^{*} \\
(0.518)\end{array}$ & $\begin{array}{l}-1.052^{* *} \\
(0.513)\end{array}$ & $\begin{array}{l}-0.894 \\
(0.664)\end{array}$ & $\begin{array}{l}-0.799 \\
(0.702)\end{array}$ & $\begin{array}{c}1.826 \\
(2.456)\end{array}$ & $\begin{array}{c}1.853 \\
(1.900)\end{array}$ \\
\hline$\Delta$ Population(s-1) & $\begin{array}{l}1.147^{* *} \\
(0.485)\end{array}$ & $\begin{array}{l}1.114^{\star *} \\
(0.472)\end{array}$ & $\begin{array}{l}1.303^{\star *} \\
(0.512)\end{array}$ & $\begin{array}{l}1.250^{\star *} \\
(0.487)\end{array}$ & $\begin{array}{c}0.545 \\
(0.146)\end{array}$ & $\begin{array}{c}0.548 \\
(1.244)\end{array}$ \\
\hline$\Delta$ Member of EU (s-1) & $\begin{array}{l}3.614^{* * *} \\
(1.225)\end{array}$ & $\begin{array}{l}4.215^{\star * *} \\
(1.214)\end{array}$ & $\begin{array}{l}-9.260^{* *} \\
(3.767)\end{array}$ & $\begin{array}{l}-6.932^{*} \\
(3.930)\end{array}$ & $\begin{array}{l}6.718^{* * *} \\
2.315\end{array}$ & $\begin{array}{l}6.727^{* * *} \\
(2.485)\end{array}$ \\
\hline $\begin{array}{l}\Delta \text { World Communist Party } \\
\text { VoteShares }(0,1)\end{array}$ & $\begin{array}{l}2.981^{* *} \\
(1.294)\end{array}$ & $\begin{array}{l}2.928^{* *} \\
(1.275)\end{array}$ & $\begin{array}{l}3.853^{* *} \\
(1.662)\end{array}$ & $\begin{array}{l}3.802^{* *} \\
(1.669)\end{array}$ & $\begin{array}{c}2.994 \\
(2.519)\end{array}$ & $\begin{array}{c}3.017 \\
(2.627)\end{array}$ \\
\hline $\begin{array}{l}\Delta \text { World Average Global } \\
\text { CapitalOpenness }(0,1)\end{array}$ & $\begin{array}{c}0.250 \\
(0.165)\end{array}$ & $\begin{array}{c}0.247 \\
(0.161)\end{array}$ & $\begin{array}{l}0.396^{* *} \\
(0.200)\end{array}$ & $\begin{array}{l}0.390 * \\
(0.203)\end{array}$ & $\begin{array}{c}0.139 \\
(0.267)\end{array}$ & $\begin{array}{c}0.142 \\
(0.271)\end{array}$ \\
\hline$\Delta$ Int'l Assets(s-1) & $\begin{array}{l}-0.265 \\
(0.514)\end{array}$ & $\begin{array}{l}-0.195 \\
(0.546)\end{array}$ & $\begin{array}{l}-0.751 \\
(0.646)\end{array}$ & $\begin{array}{l}-0.626 \\
(0.657)\end{array}$ & $\begin{array}{l}-1.339 \\
(1.158)\end{array}$ & $\begin{array}{l}-1.392 \\
(1.906)\end{array}$ \\
\hline$\Delta$ Int'l Liabilities (s-1) & $\begin{array}{l}-1.457^{*} \\
(0.879)\end{array}$ & $\begin{array}{l}-1.441^{*} \\
(0.850)\end{array}$ & $\begin{array}{l}-0.199 \\
(0.816)\end{array}$ & $\begin{array}{l}-0.315 \\
(0.785)\end{array}$ & $\begin{array}{l}-4.363^{* *} \\
(2.044)\end{array}$ & $\begin{array}{l}-4.334^{*} \\
(2.599)\end{array}$ \\
\hline r-square (=1-(rss/tss)) & 0.74 & 0.74 & 0.76 & 0.77 & 0.75 & 0.75 \\
\hline AR1 & $\begin{array}{c}04.100 \\
(0.000)^{\star *}\end{array}$ & $\begin{array}{c}-4.089 \\
(0.000)^{* *}\end{array}$ & $\begin{array}{l}-3.133 \\
(0.002)\end{array}$ & $\begin{array}{c}-3.091 \\
(0.002)^{\star *}\end{array}$ & $\begin{array}{c}-3.399 \\
(0.001)^{\star *}\end{array}$ & $\begin{array}{c}-3.339 \\
(0.001)^{\star *}\end{array}$ \\
\hline AR2 & $\begin{array}{c}-0.7359 \\
(0.462)\end{array}$ & $\begin{array}{l}-0.533 \\
(0.587)\end{array}$ & $\begin{array}{l}-0.439 \\
(0.661)\end{array}$ & $\begin{array}{c}-0.427 \\
(0.669)\end{array}$ & $\begin{array}{l}-0.438 \\
(0.662)\end{array}$ & $\begin{array}{c}-0.450 \\
(0.653)\end{array}$ \\
\hline Number of Obs & 374 & 374 & 255 & 255 & 112 & 112 \\
\hline Countries & 77 & 77 & 56 & 56 & 20 & 20 \\
\hline Intercept & $\begin{array}{c}0.290 \\
(18.19)\end{array}$ & $\begin{array}{c}7.171 \\
(19.39)\end{array}$ & $\begin{array}{l}-20.548 \\
(21.30)\end{array}$ & $\begin{array}{c}-11.792 \\
(22.34)\end{array}$ & $\begin{array}{l}-26.633 \\
(68.11)\end{array}$ & $\begin{array}{l}-29.056 \\
(113.70)\end{array}$ \\
\hline
\end{tabular}


Appendix Table 1. Corporate Tax Revenues as a Percentage of GDP

\begin{tabular}{|c|c|c|c|c|c|}
\hline Variable & $\begin{array}{l}\text { Model } 1 \\
\text { Full sample }\end{array}$ & $\begin{array}{l}\text { Model } 2 \\
\text { nonOECD }\end{array}$ & $\begin{array}{c}\text { Model } 3 \\
\text { nonOECD }\end{array}$ & $\begin{array}{l}\text { Model } 4 \\
\text { OECD }\end{array}$ & $\begin{array}{l}\text { Model } 5 \\
\text { OECD }\end{array}$ \\
\hline Corporate Revenue (s-1) & $\begin{array}{l}0.797^{* * *} \\
(0.098)\end{array}$ & $\begin{array}{c}0.742^{* * *} \\
(0.103)\end{array}$ & $\begin{array}{c}0.479^{* * *} \\
(0.162)\end{array}$ & $\begin{array}{l}1.042^{* * *} \\
(0.046)\end{array}$ & $\begin{array}{l}0.735^{\star * *} \\
(0.106)\end{array}$ \\
\hline Corporate Tax Rates (s-1) & $\begin{array}{l}0.076^{* *} \\
(0.034)\end{array}$ & $\begin{array}{c}0.126^{* *} \\
(0.06)\end{array}$ & $\begin{array}{l}0.101^{* *} \\
(0.046)\end{array}$ & $\begin{array}{l}-0.009 \\
(0.018)\end{array}$ & $\begin{array}{l}0.061^{*} \\
(0.036)\end{array}$ \\
\hline $\begin{array}{l}\text { Home Capital Tax Rates minus } \\
\text { U.S. Capital Tax Rates (s-1) }\end{array}$ & $\begin{array}{l}-0.046^{*} \\
(0.025)\end{array}$ & $\begin{array}{l}-0.087^{* *} \\
(0.043)\end{array}$ & $\begin{array}{l}-0.085^{*} \\
(0.045)\end{array}$ & $\begin{array}{l}-0.021 \\
(0.019)\end{array}$ & $\begin{array}{c}-0.062^{* *} \\
(0.03)\end{array}$ \\
\hline $\begin{array}{l}\text { Home Capital Tax Rates minus } \\
\text { U.S. Capital Tax Rates SQUARED } \\
\text { (s-1) }\end{array}$ & $\begin{array}{c}0.0001 \\
(0.0004)\end{array}$ & $\begin{array}{l}0.0001 \\
(0.0004)\end{array}$ & $\begin{array}{c}0.0002 \\
(0.0005)\end{array}$ & $\begin{array}{l}-0.0004 \\
(0.0004)\end{array}$ & $\begin{array}{l}-0.0018^{* *} \\
(0.0008)\end{array}$ \\
\hline$\triangle C A P I T A L(s-1)$ & $\begin{array}{l}0.012^{* *} \\
(0.005)\end{array}$ & $\begin{array}{c}0.009 \\
(0.006)\end{array}$ & $\begin{array}{l}-0.008 \\
(0.007)\end{array}$ & $\begin{array}{c}0.002 \\
(0.006)\end{array}$ & $\begin{array}{l}0.020 \\
(0.016)\end{array}$ \\
\hline $\begin{array}{l}\Delta \text { Economic Growth } \\
\text { (s-1]) }\end{array}$ & $\begin{array}{l}0.141^{*} \\
(0.079)\end{array}$ & $\begin{array}{c}0.132 \\
(0.086)\end{array}$ & $\begin{array}{c}0.078 \\
(0.084)\end{array}$ & $\begin{array}{l}-0.034 \\
(0.041)\end{array}$ & $\begin{array}{l}-0.067 \\
(0.114)\end{array}$ \\
\hline$\Delta$ Income (s-1) & $\begin{array}{c}0.347 \\
(0.223)\end{array}$ & $\begin{array}{c}0.514 \\
(0.411)\end{array}$ & $\begin{array}{c}1.322 \\
(0.929)\end{array}$ & $\begin{array}{c}-1.234^{\star *} \\
(0.559)\end{array}$ & $\begin{array}{c}2.034 \\
(4.196)\end{array}$ \\
\hline $\begin{array}{l}\Delta \text { Investment (s-1) } \\
(\text { Share of GDP) }\end{array}$ & $\begin{array}{l}-0.046 \\
(0.283)\end{array}$ & $\begin{array}{c}0.048 \\
(0.251)\end{array}$ & $\begin{array}{l}-0.152 \\
(0.455)\end{array}$ & $\begin{array}{l}-2.610^{* *} \\
(1.112)\end{array}$ & $\begin{array}{c}-3.873^{* * *} \\
(1.077)\end{array}$ \\
\hline$\Delta$ Government Share of GDP $(\mathrm{s}-1)$ & $\begin{array}{l}0.011 \\
(0.01)\end{array}$ & $\begin{array}{c}0.000 \\
(0.013)\end{array}$ & $\begin{array}{l}0.036 \\
(0.022)\end{array}$ & $\begin{array}{c}0.009 \\
(0.017)\end{array}$ & $\begin{array}{l}-0.065 \\
(0.092)\end{array}$ \\
\hline$\Delta$ Trade Openness(s-1) & $\begin{array}{c}0.054 \\
(0.175)\end{array}$ & $\begin{array}{l}-0.132 \\
(0.23)\end{array}$ & $\begin{array}{l}0.076 \\
(0.794)\end{array}$ & $\begin{array}{l}0.604^{\star *} \\
(0.275)\end{array}$ & $\begin{array}{l}-2.023 \\
(2.369)\end{array}$ \\
\hline$\Delta$ Member of EU (s-1) & $\begin{array}{l}-0.636^{* *} \\
(0.317)\end{array}$ & $\begin{array}{l}-0.900 \\
(1.945)\end{array}$ & $\begin{array}{c}1.211 \\
(0.995)\end{array}$ & $\begin{array}{l}-0.754^{\star *} \\
(0.365)\end{array}$ & $\begin{array}{l}-0.669^{* *} \\
(0.321)\end{array}$ \\
\hline$\Delta$ Financial Development & $\begin{array}{l}-0.247 \\
(0.379)\end{array}$ & $\begin{array}{c}0.610 \\
(0.695)\end{array}$ & $\begin{array}{l}-1.136 \\
(1.436)\end{array}$ & $\begin{array}{l}-0.554 \\
(0.334)\end{array}$ & $\begin{array}{l}-1.235 \\
(1.093)\end{array}$ \\
\hline Time Trend & $\begin{array}{l}0.06^{* * *} \\
(0.021)\end{array}$ & $\begin{array}{l}0.089^{* *} \\
(0.038)\end{array}$ & $\begin{array}{l}0.091^{* *} \\
(0.038)\end{array}$ & $\begin{array}{l}0.074^{* *} \\
(0.035)\end{array}$ & $\begin{array}{c}0.128 \\
(0.151)\end{array}$ \\
\hline$\Delta$ Assets (s-1) & $\begin{array}{l}-0.263 \\
(0.221)\end{array}$ & $\begin{array}{l}-0.312 \\
(0.279)\end{array}$ & $\begin{array}{l}0.063 \\
(0.33)\end{array}$ & $\begin{array}{c}0.636 \\
(0.419)\end{array}$ & $\begin{array}{l}0.889^{* *} \\
(0.397)\end{array}$ \\
\hline$\Delta$ Liabilities (s-1) & $\begin{array}{l}0.326 \\
(0.229)\end{array}$ & $\begin{array}{l}0.505 \\
(0.37)\end{array}$ & $\begin{array}{l}-0.105 \\
(0.509)\end{array}$ & $\begin{array}{c}-1.430^{* *} \\
(0.557)\end{array}$ & $\begin{array}{c}-1.712^{* * *} \\
(0.487)\end{array}$ \\
\hline Adjusted R-square & 0.737 & 0.761 & 0.887 & 0.819 & 0.888 \\
\hline ABM1 & {$[0.016]^{\star *}$} & {$[0.054]^{*}$} & {$[0.014]^{* *}$} & {$[0.027]^{* *}$} & {$[0.050]^{* *}$} \\
\hline ABM2 & {$[0.570]$} & [0.375] & {$[0.650]$} & {$[0.066]$} & {$[0.237]$} \\
\hline Fixed Effects & $\mathrm{n}$ & $\mathrm{n}$ & $\mathrm{y}$ & $\mathrm{n}$ & $\mathrm{Y}$ \\
\hline Number of Obs & 245 & 137 & 137 & 108 & 108 \\
\hline Countries & 60 & 38 & 38 & 22 & 22 \\
\hline Intercept & $\begin{array}{c}-126.615^{* * *} \\
(45.57)\end{array}$ & $\begin{array}{c}-187.646^{* *} \\
(81.01)\end{array}$ & $\begin{array}{c}-193.26^{\star *} \\
(74.64)\end{array}$ & $\begin{array}{l}-125.693^{*} \\
(64.96)\end{array}$ & $\begin{array}{c}-252.228 \\
(262.6)\end{array}$ \\
\hline
\end{tabular}


Appendix Table 2. Country Classification

\begin{tabular}{|c|c|c|c|c|}
\hline $\begin{array}{l}\text { Emerging Market } \\
\text { Upper Income }\end{array}$ & $\begin{array}{l}\text { Emerging Market } \\
\text { Lower Income }\end{array}$ & OECD Non-bank & Tax Havens & OPEC \\
\hline Albania & Bangladesh & Australia & Bahamas & Algeria \\
\hline Argentina & Botswana & Austria & Bahrain & Ecuador \\
\hline \multirow[t]{2}{*}{ Bolivia } & Burkina & Belgium & Barbados & Gabon \\
\hline & Cambodia & Canada & Hong Kong & Indonesia \\
\hline Brazil & Cameroon & Denmark & Ireland & Iran \\
\hline Bulgaria & China & Finland & Mauritius & Iraq \\
\hline Chile & Congo (Republic of the) & France & Panama & Libya \\
\hline Colombia & Ethiopia & Germany & Singapore & Nigeria \\
\hline Costa Rica & Ghana & Greece & Switzerland & Saudi Arabia \\
\hline Czech Republic & Haiti & Iceland & & Trinidad and Tobage \\
\hline Dominican Republic & India & Italy & & Venezuela \\
\hline Egypt & Kenya & Japan & & \\
\hline Fiji & Laos & Netherlands & & \\
\hline Guatemala & Madagascar & New Zealand & & \\
\hline Honduras & Mozambique & Norway & & \\
\hline Hungary & Myanmar & Portugal & & \\
\hline Israel & Nepal & Spain & & \\
\hline Ivory Coast & Pakistan & Sweden & & \\
\hline Jamaica & Rwanda & United Kingdom & & \\
\hline Jordan & Senegal & United States & & \\
\hline Korea & Sierra Leone & & & \\
\hline Malaysia & Sri Lanka & & & \\
\hline Mexico & Sudan & & & \\
\hline Paraguay & Syria & & & \\
\hline Peru & Tanzania & & & \\
\hline Philippines & Uganda & & & \\
\hline Poland & Vietnam & & & \\
\hline Romania & Zambia & & & \\
\hline Russia & Zimbabwe & & & \\
\hline Salvador & & & & \\
\hline Slovakia & & & & \\
\hline South Africa & & & & \\
\hline Thailand & & & & \\
\hline Tunisia & & & & \\
\hline Turkey & & & & \\
\hline Uruguay & & & & \\
\hline
\end{tabular}




\section{References}

Aizenman, Joshua, and Yothin Jinjarak. 2009. "Globalization and Developing Countries: A Shrinking Tax Base?” Journal of Development Studies 45(5):653-671.

Altshuler, Roberta, and T.J. Goodspeed (2002). 'Follow the leader? Evidence on European and U.S. tax competition', Working paper, Department of Economics, Rutgers University. 2002-26. available from http://ideas.repec.org

Auerbach, A. J., Devereux, M. P., and Simpson, H. (2007), 'Taxing Corporate Income', Centre for BusinessTaxation Working Paper 07/05.

Auerbach, Alan J., and Kevin A. Hassett. 2002. "A New Measure of Horizontal Equity." American Economic Review 92(4):1116-25.

Baldwin, Robert E., and Paul Krugman. 2004. "Agglomeration, Integration, and Tax Harmonization." European Economic Review 48(1):1-23.

Basinger, Scott J., and Mark Hallerberg. 2004. "Remodeling the Competition for Capital: How Domestic Erases the Race to the Bottom." American Political Science Review 98(1):261-276.

Beck, Thoresten, A. Deriguc-Kunt, and Ross Levine. 2000. "A New Database on the Structure and Development of the Financial Sector." World Bank Economic Review 14(3):597-605.

Berman, Elizabeth Popp, and Nicholas Pagnucco. 2010. "Economic Ideas and the Political Process: Debating Tax Cuts in the U.S. House of Representatives, 1962-1981." Politics and Society 38(3):347-372.

Blundell, R. W., and S. R. Bond. 1998. "Initial conditions and moment restrictions in dynamic panel data models. " Journal of Econometrics 87: 115-43.

Boix, Carles. 2003. Democracy and Redistribution. New York: Cambridge University Press.

Boskin, Michael J. 1996. "Tax Reforms Worth Making if Changes Have Staying Power." Los Angles Times April 14

Bretschger, Lucas, and Frank Hettich. 2002. ' Globalization, Capital Mobility and Tax Competition: Theory and Evidence for OECD Countries.' European Journal of Political Economy 18 (4): 695-716.

Cao, Xun. 2010. "Networks as Channels of Policy Diffusion: Explaining Worldwide Changes in Capital Taxation, 1998-2006." International Studies Quarterly 54(3):823-854. 
Chwieroth, Jeffrey M. 2010. Capital Ideas: The IMF and the Rise of Financial Liberalization. New York: Princeton University Press.

Chwieroth, Jeffrey M. 2007. "Neoliberal Economists and Capital Account Liberalization." International Organization 61(2):443-463.

Clark, William R., and Mark Hallerberg. 2000. “Mobile Capital, Domestic Institutions, and Electorally Induced Monetary and Fiscal Policy.' American Political Science Review 94 (2): 323-346.

Clausing, K. A. (2007), 'Corporate Tax Revenues in OECD Countries', International Tax and Public Finance, 14, 115-34.

Congressional Budget Office, 2005, “Corporate Income Tax Rates: International Comparisons", CBO, Washington, D.C.

Davies, David G. 1986. United States Taxes and Tax Policy. New York: Cambridge University Press.

De Mooij, Rudd A., and Sjef Ederveen. 2008. “Corporate Tax Elasticities: A Reader's Guide to Empirical Findings." Oxford Review of Economic Policy 24(4):680-697.

Desai, Mihir A., and Dhammika Dharmapala. 2010. "Do Strong Fences Make Strong Neighbors?" National Tax Journal 63(4,1):723-40.

Desai, Mihir A., C. Fritz Foley, and James R. Hines, Jr. 2004. "Foreign Direct Investment in a World of Multiple Taxes" Journal of Public Economics 59(6):2727-2744.

Devereux, M. P. (2008), 'Taxation of Outbound Direct Investment: Economic Principles and Tax Policy Considerations', Oxford Review of Economic Policy, 24(4), 698-19.

Devereux, M.P., Lockwood, B., Redoano, M., 2008. Do countries compete over corporate tax rates? Journal of Public Economics 92, 1210-1235.

Devereux, Michael P., Ben Lockwood, and Michela Redoano. 2007. "Do Countries Compete Over Corporate Tax Rates?” Journal of Public Economics 92(5-6):12101235.

Devereux, Michael P., Rachel Griffith, and Alexander Klemm. 2002. 'Corporate Income Tax Reforms and International Tax Competition.' Economic Policy 17 (35): 449_ 495.

Dollar, David, and Aart Kraay. 2002. "Growth is Good for the Poor," Journal of Economic Growth

Doornik, Jurgen, and David F. Hendry. 2001. Econometric Modeling Using PCGive 10: Volume III. London: Timberlake Consultants. 
Dreher, A., 2006. The influence of globalization on taxes and social policy: an empirical analysis for OECD countries. European Journal of Political Economy 22, 179-201.

Drucker, Jesse. 2011. "Dodging Repatriation Tax Lets U.S. Companies Bring Home Cash." Bloomberg Business Week. Accessed at: http://www.businessweek.com/news/201101-05/dodging-repatriation-tax-lets-u-s-companies-bring-home-cash.html.

Edwards, J., Keen, M., 1996. Tax competition and Leviathan. European Economic Review $40,113-134$.

Eggert, W., Sorensen, P.B., 2008. The effects of tax competition when politicians create rents to buy political support. Journal of Public Economics 92, 1142-1163.

Freeman, John R., and Dennis P. Quinn. 2012. "The Economic Origins of Democracy Reconsidered." American Political Science Review 102(1):58-80.

Frenkel, Jacob A., Assaf Razin, and Efraim Sadka. 1991. International Taxation in an Integrated World. Cambridge: MIT.

Friedrich, Robert J. 1982. "In Defense of Multiplicative Terms in Multiple Regression Equations." American Journal of Political Science 26(November): 797-833.

Garrett, Geoffrey, 1995. "Capital Mobility, Trade, and the Domestic Politics of Economic Policy." International Organization 49 (Autumn):657-87.

, 1998a, "Global Markets and National Politics: Collision Course or Virtuous

Circle?' International Organization 52 (4): 787-824.

, 1998b. Partisan Politics in the Global Economy. Cambridge: Cambridge University Press.

Genschel, Philipp, and Thomas Plömper. 1997. "Regulatory Competition and International Cooperation.' Journal of European Public Policy 4 (4): 626-642.

Genschel, Philipp. 2002. “'Globalization, Tax Competition, and the Welfare State.' Politics and Society 30 (2): 245-275.

Gordon, Roger H. 1992. "Can Capital Income Taxes Survive in Open Economies?" Journal of Finance 47(July):1159-80.

Gordon, Roger H., and A. Lans Bovenberg. 1996. "Why Is Capital So Immobile Internationally?” American Economic Review 86(December):1057-1075.

Gravelle, Jane G., 1994, The Economic Effects of Taxing Capital Income. Cambridge: MIT Press.

1995, "The Corporate Income Tax: Economic Issues and Policy Options." National Tax Journal 48(2):267-277. 
,2010, "Tax Havens: International Tax Avoidance and Evasion," Congressional Research Service Report \#R40623, 3 September. Washington, D.C.:CRS.

Hallerberg, Mark, and Scott J. Basinger. 1999. “'Globalization and Tax Reform: An Updated Case for the Importance of Veto Players.' ' Politische Vierteljahresschrift 40 (4): 618627.

Hassett, Kevin A., and R. Glenn Hubbard (eds.). 2001. Transitions Costs of Fundamental Economic Reform. Washington, D.C.: AEI.

Haufler, A., Klemm, A., Schjederup, G., 2008. Redistributive taxation, multinational enterprises, and economic integration. European Journal of Political Economy 24, 249-255.

Haufler, Andreas. 2001. Taxation in a Global Economy: Theory and Evidence. New York: Cambridge University Press.

Hays, Jude C. 2003. "Globalization and Capital Taxation in Consensus and Majoritarian Democracies." World Politics 56 (1): 79-113.

Henisz, Witold, Bennet Zelner, and Mauro F. Guillen. 2005. "The Worldwide Diffusion of Market-Oriented Infrastructure Reforms, 1977-1999.” American Sociological Review 70(6):871-897.

Heston, A., R. Summers, and B. Aten. 2006. The Penn World Table, Version 6.2. Center for International Comparisons of Production, Income and Prices at the University of Pennsylvania, September.

Hines, James R., Jr. 2005. “Corporate Taxation and International Competition.” University of Michigan, Ross School of Business Typescript Manuscript, \#1026.

Hines, James R., Jr., and Lawrence H. Summers. 2009. How Globalization Affects Tax Design. Cambridge: NBER Working Paper 14664.

Houle, Christian 2009. "Inequality and Democracy: Why Inequality Harms Consolidation but Does Not Affect Democratization” World Politics 61(4): 589-622.

Hoyt, William H. 1991. ' Property Taxation, Nash Equilibrium, and Market Power.' Journal of Urban Economics 34 (1): 123-131.

Huizinga, H., Nielsen, S.P., 1997. Capital income and profit taxation with foreign ownership of firms. Journal of International Economics 42, 149-165.

Inclan, Cala, Dennis P. Quinn, Robert Y. Shapiro. 2001. "Origins and Consequences of U.S. Corporate Taxation, 1981-1998. American Journal of Political Science 45(1):179-201 
International Monetary Fund, (annual) Government Financial Statistics Yearbook. Washington, D.C.: IMF.

, 1993, Balance of Payments Manual, $5^{\text {th }}$ ed. Washington, D.C.: IMF.

, 1997, International Financial Statistics, June 1997. Washington, D.C.: IMF.

, Annual Report on Exchange Restrictions. Various years, 1950 on International

Monetary Fund. Continued by Annual Report on Exchange Arrangements and

Exchange Restrictions after 1979 and Exchange Arrangements and Exchange

Restrictions after 1989.

, 2010. "Post-Crisis Fiscal Policy: A Status Update on Exit Strategies", IMF Staff Paper.

, 2012a. Fiscal Monitor, October 2012. Washington, D.C. IMF.

Joint Committee on Taxation. 2008. Economic Efficiency and Structural Analyses of Alternative U.S. Tax Policies for Foreign Direct Investment (25 June). GPO: JCS55-08, Washington, D.C.

Kanbur, Ravi, and Michael Keen. 1993. “Jeux Sans Frontier: Tax Competition and Tax Coordination When Countries Differ in Size.” American Economic Review 83 (4): 877-892.

Kanniainen, Vesa, and Jan Södersten. 1995. "The Importance of Reporting Conventions for the Theory of Corporate Taxation." Journal of Public Economics 57:417-30.

Keen, Michael, and Maurice Marchand. 1997. "Fiscal Competition and the Pattern of Public Spending." Journal of Public Economics 66 (1): 33-53.

Kempf, Hubert, and Gregoire Rota-Graziosi, 2010, "Endogenizing Leadership in Tax Competition." Journal of Public Economics 94(9/10):768-776.

Krogstrup, Signe, 2008, "Standard Tax Competition and Increasing Returns." Journal of Public Economic Theory 10(4):547-561.

Kumar, Manmohan S., T. Bayoumi, G. Fazio, and R. MacDonald. 2007. "Fatal AttractionAnalysis of Financial Contagion." International Finance, Fall 2007.

Kumar, Manmohan S., Jiri Jonas and David Hauner, 2007, "Fiscal Policies, Financial Markets, and Globalization," IMF Working Paper.

Lane, P.R., and G. M. Milesi-Ferretti. 2006. The External Wealth of Nations Mark II: Revised and Extended Estimates of Foreign Assets and Liabilities, 1970-2004. IMF Working Paper No. 06/69 
2007, The External Wealth of Nations, Mark II: Revised and Extended Estimates of Foreign Assets and Liabilities, 1970-2004. Journal of International Economics 73: 223-250.

Lockwood, B., Makris, M., 2006. Tax incidence, majority voting and capital market integration. Journal of Public Economics 90, 1007-1025.

Loretz, S. (2008), 'Corporate Taxation in the OECD in a Wider Context', Oxford Review of Economic Policy, 24(4), 639-60.

Obstfeld, Maurice, and Alan M. Taylor, 1999, Global Capital Markets: Integration, Crisis, and Growth. Cambridge: Cambridge University Press.

OECD National Accounts. 2010. Corporate Tax Base, Table II.1. Paris: Organization for Economic Co-operation and Development.

OECD Revenue Statistics. 2006. Revenue Statistics 1975-2005. Various Issues. Paris: Organization for Economic Co-operation and Development.

OECD. 2010. Tax Policy Reform and Economic Growth: OECD Tax Policy Studies. Paris: OECD.

Plümper, Thomas, Vera E. Troeger, and Philip Manow. 2005. "Panel Data Analysis in Comparative Politics: Linking Method to Theory.' European Journal of Political Research 44 (2): 327-354.

Plümper, Thomas, Vera Tröger, and Hannes Winner. 2009. "Why Is There No Race to the Bottom in Capital Taxation?" International Studies Quarterly In Press.

Price Waterhouse. (Various.) Corporate Taxes: A World-Wide Summary. Washington: PW.

Quinn, Dennis P. and A. M. Toyoda. 2007. Ideology and voter sentiment as determinants of financial globalization. American Journal of Political Science 51(April): 344-363.

Quinn, Dennis. 1997. "The Correlates of Change in International Financial Regulation.” American Political Science Review 91(September):531-51.

Quinn, Dennis P. and Robert Y. Shapiro. 1991. "Business Political Power: the Case of Taxation" American Political Science Review 85(September):856-871.

Razin, A., Sadka, E., 1991. Efficient investment incentives in the presence of capital flight. Journal of International Economics 31, 171-181.

Razin, Assaf and Efraim Sadka. 2004. "Capital Income Taxation in a Globalized World”, NBER \#10630 
Richter, Brian K., Krislert Samphantharak, and Jeffrey F. Timmons. 2009. "Lobbying and Taxes." American Journal of Political Science 53(4):893-909.

Rodriguez, Francisco, and Daniel Ortega. 2006. "Are Capital Shares Higher in Poor Countries? Evidence from Industrial Surveys." Wesleyan Economics Working Papers, \#2006-023. accessed at www.repec.wesleyan .edu.

Rodrik, D., van Ypersele, T., 2001. Capital mobility, distributive conflict and international tax coordination. Journal of International Economics 54, 57-73.

Slemrod, Joel. 2004. “Are Corporate Tax Rates, Or Countries, Converging?” Journal of Public Economics 88 (6): 1169-1186.

Stewart, Kenneth and Michael Webb. 2006. "International Competition in Corporate Taxation: Evidence From OECD Time Series.” Economic Policy 45(January):153201.

Swank, Duane H. 1998. "Funding the Welfare State: Globalization and the Taxation of Business in Advanced Market Economies.' Political Studies 46 (4): 671-692. ,2006, “Tax Policy in an Era of Internationalization: An Assessment of a Conditional Diffusion Model of the Spread of Neoliberalism.' International Organization 60 (4): 847-882.

Swank, Duane, and Sven Steinmo. 2002. "The New Political Economy of Taxation in Advanced Capitalist Democracies.” American Journal of Political Science. 46(3):642-655.

Tanzi, Vito. 1995. Taxation in an Integrated World. Washington: Brookings. , 1996, "Globalization and Tax Competition.” IMF Staff Working Paper WP 96/141.

, 1998, "Fundamental Determinants of Inequality and the Role of Government." Washington, D.C.: IMF Working Paper, 98/178 (Washington: International Monetary Fund).

, 1995, “Taxation in an Integrated World," (Washington: Brookings Institution).

UTIP-UNIDO, 2002, Wage Inequality. The University of Texas Inequality Project. Austin, TX: University of Texas.

Williams, John T., and Brian C. Collins. 1997. "The Political Economy of Taxation." American Journal of Political Science 41(January): 208-44.

Wilson, John D., 1987. Trade, capital mobility and tax competition. Journal of Political Economy 95, pp. 835-56. 
Wilson, John D. 1999. “Theories of Tax Competition.” National Tax Journal 52 (2): 269 304.

Wilson, John D., and David E. Wildasin. 2004. “Tax Competition: Bane or Bone?’ Journal of Public Economics 88 (6): 1065-91.

World Bank 2006. World Development Indicators, CD-ROM. Washington, D.C.: The World Bank.

Zodrow, George R., Mieszkowski, Peter. 1986. Pigou, Tiebout, property taxation and the underprovision of local public goods. Journal of Urban Economics 19, 356-370.

Zodrow, George R. 2010. "Capital Mobility and Capital Tax Competition." National Tax Journal 63(4,1):865-902. 